Golden Gate University School of Law GGU Law Digital Commons

2014

\title{
Owning Oneself In a World of Others: Towards a Paid-For First Amendment
}

David Franklyn

Golden Gate University School of Law, dfranklyn@ggu.edu

Adam Kuhn

Follow this and additional works at: https://digitalcommons.law.ggu.edu/pubs

Part of the Intellectual Property Law Commons

\section{Recommended Citation}

49 Wake Forest L. Rev. 977 (2014).

This Article is brought to you for free and open access by the Faculty Scholarship at GGU Law Digital Commons. It has been accepted for inclusion in Publications by an authorized administrator of GGU Law Digital Commons. For more information, please contact jfischer@ggu.edu. 


\title{
OWNING ONESELF IN A WORLD OF OTHERS: TOWARDS A PAID-FOR FIRST AMENDMENT
}

\author{
David Franklyn"\& Adam Kuhn**
}

Can the right of publicity (a state-law right) be reconciled (in a legitimate and nonarbitrary way) with the First Amendment's prohibition against state laws that "suppress" speech? Ever since the Supreme Court said that commercial speech deserves First Amendment protection, defendants have used it as a defense when accused of misappropriating celebrity fame for profit. 1 The analysis has morphed in the case law to the point that the controlling issue seems to be whether the challenged use is "sufficiently transformative" to justify the taking. ${ }^{2}$ The use of a transformation construct to manage the conflict has been dubious at best and misleading at worst. It has spawned an inconsistent and increasingly arbitrary body of law.

After decades of sitting on the sidelines, the Supreme Court was set to squarely address the problem in a case involving a college football videogame; however, by stipulation of the parties, the Court dismissed the petition for writ of certiorari. ${ }^{3}$ Former college athletes (who are contractually limited from commercial exploitation of their likenesses while in school) sued the NCAA and Electronic Arts ("EA"), claiming that videogames made under NCAA licensing deals violated their rights of publicity by misappropriating their

* Professor of Law, The University of San Francisco School of Law; Executive Director, McCarthy Institute for Intellectual Property and Technology Law.

** Senior Research Fellow, McCarthy Institute for Intellectual Property and Technology Law.

1. EnCYCLOPEDia of THE First AmEndment 893 (John R. Vile et al. eds., 2009).

2. Id. at 436 (discussing "transformative" use).

3. See In re NCAA Student-Athlete Name \& Likeness Licensing Litig. (Keller), 724 F.3d 1268 (9th Cir. 2013); cert. dismissed, No. 13-377 (U.S. Sept. 30, 2013), available at http://www.supremecourt.gov/Search.aspx? FileName =/docketfiles/13-377.htm; see also Steve Berkowitz, NCAA Vows to Fight O'Bannon Suit to the Supreme Court, USA TODAY (Sept. 26, 2013, 3:13 PM), http://www.usatoday.com/story/sports/ncaab/2013/09/26/ncaa-ed-obannon-easports-lawsuit-supreme-court/2877579/ (noting that Donald Remy, NCAA Chief Legal Officer, told USA Today Sports, "We're prepared to take this all the way to the Supreme Court if we have to."). 
likenesses.4. The defense claimed that any such uses of their likenesses-even though blatantly commercial-were protected by the First Amendment freedom of speech. ${ }^{5}$ It would have been the first time in almost forty years that the Supreme Court addressed the right of publicity and may have been the last opportunity to reconcile an otherwise inconsistent and unpredictable body of law for the digital age. ${ }^{6}$

Most courts that have addressed similar issues have attempted some sort of "balancing" of the right of publicity (conceived as a property right) against the First Amendment (usually conceived as a right to freely express oneself, albeit for profit in this instance by using a famous person's persona or likeness). ${ }^{7}$ The profit motive, it is often said, does not strip the use of First Amendment protection because the Supreme Court has made clear that commercial speech, whatever that is, still deserves significant First Amendment protection. ${ }^{8}$

This Article argues that the courts' conceptualization of the conflict-as a property right against a speech right-is askew. We argue that the conflict is really about allocating competing economic claims: the right of the plaintiff to prevent commercial use of her image versus the right of the defendant to make commercial use of that image. The transformative use test essentially turns the inquiry into an attempt, albeit not transparent, to allocate the economic value created by, or attributable to, the celebrity plaintiff against the add-on value created by the defendant who took the celebrity image and allegedly transformed it into a new product with

4. Third Consolidated Amended Class Action Complaint, In re NCAA Student-Athlete Name \& Likeness Licensing Litig., No. C 09-01967 CW (N.D. Cal. July 19, 2013), 2013 WL 3810438. EA has since agreed to settle with the plaintiffs and pay $\$ 40$ million to the class. The NCAA had refused to settle and sought to intervene in the settlement. See Steve Berkowitz, NCAA Sues Video Game Maker, Licensing Firm, USA TODAY (Nov. 20, 2013, 8:39 PM), $\mathrm{http} / / \mathrm{www}$.usatoday.com/story/sports/college/2013/11/20

/ncaa-electronic-arts-collegiate-licensing-co-lawsuit/3657103/.

5. Electronic Arts Inc.'s Answer to Antitrust Allegations in Second Consolidated Amended Class Action Complaint at 62, In re NCAA StudentAthlete Name \& Likeness Licensing Litig., No. C 09-3329 CW, (N.D. Cal. Aug. 8, 2014), 2014 WL 3899815 (listing "First Amendment" as an affirmative defense).

6. See Daniel Nazer, Ninth Circuit Rules that Celebrity "Rights" Trump Free Speech, ELECTRONIC FRONTIER FOUND. (July 31, 2013), https://www.eff.org /deeplinks/2013/07/ninth-circuit-says-celebrities-are-more-important-freespeech (describing potential legal and policy implications of the dispute).

7. ENCYCLOPEDIA OF THE FIRST AMENDMENT, supra note 1, at 106 (discussing cases where the right to publicity was limited by the First Amendment).

8. See, e.g., Bigelow v. Virginia, 421 U.S. 809,818 (1975) ("The fact that the particular advertisement in appellant's newspaper had commercial aspects or reflected the advertiser's commercial interests did not negate all First Amendment guarantees."). 
new economic value attributable to the defendant's own work or creativity.

The issue we identify is that a loosely defined doctrine of concurrent ownership (of the celebrity image) is being applied to an abstract and infinite resource, thus apportioning the plaintiff's right to use her property against the defendant's identical right to use that property - and all using a very odd and ill-fitted tool: the First Amendment. It is a very poor device to do the job it is asked to do.

We argue here that the problem cannot be fixed until the deficiency in First Amendment jurisprudence is identified: it is not designed and does not work well as a value allocation device. We further argue that the proper conceptualization of the conflict is one of shared value and proper compensation if we are to allow celebrity fame to be utilized by multiple parties besides the celebrity.

In addition to reconstructing the theoretical model of the conflict, we suggest a change to the law. The essential problem with the First Amendment as a value allocation device is that there is no precedent for using it in a way that would support judicially imposed compromise. In other words, it is a winner-take-all game. If the First Amendment defense applies, the defendant gets away with the use entirely. ${ }^{9}$ If the defense does not apply, the defendant is enjoined entirely from continuing her use-even if that use has defensible elements. ${ }^{10}$ One solution would be to jettison the First Amendment in these cases altogether and construct a fair-use defense similar to the one employed in copyright law that expressly seeks to balance creative and economic factors.

Another more radical solution would be to fundamentally change our approach to the First Amendment as a necessarily winner-take-all device for which compensation is never required. In its place, one can imagine a "paid-for" First Amendment in the form of a compulsory publicity license. Under this model, the plaintiff would not be able to censor the defendant's speech, but likewise, even the expressive and creative defendant (that is, a transformative user) could not free ride on the plaintiff's celebrity fame without having to pay fair-market-value compensation for its profit-driven use.11 In essence, the fact finder could find that the challenged use is sufficiently creative to continue but that a reasonable royalty must be paid. The royalty would be based on the

9. See, e.g., Comedy III Prods., Inc. v. Gary Saderup, Inc., 21 P.3d 797, 810 (Cal. 2001) ("[W]hen an artist is faced with a right of publicity challenge to his or her work, he or she may raise as affirmative defense that the work is protected by the First Amendment .....").

10. See, e.g., id. at 810-11 (rejecting the First Amendment defense in a case involving realistic portraitures).

11. Cf. David J. Franklyn, Debunking Dilution Doctrine: Toward a Coherent Theory of the Anti-Free-Rider Principle in American Trademark Law, 56 HASTINGS L.J. 117, 118 (2005) (observing that judges and juries tend to punish free riding in trademark law). 
value of the celebrity image and could be offset to the extent to which the transformative use derives substantial economic value from the creativity of the defendant instead of merely or mostly from the fame of the celebrity.

In many of these cases, both parties have arguably created competing or overlapping Lockean property rights.12 The shared value is similar to the allocation that ought to occur when a copyright defendant claims transformative fair use as a justification for making an unauthorized derivative work. Whether this type of economic allocation-in the right of publicity context-is made in the name of a newly constructed fair-use device or a new First Amendment jurisprudence probably does not matter. What matters is that the economic allocation at issue be transparent and that the law deals with it head-on.

Our analysis shifts the emphasis away from problematic evaluations of artistic merit (expressive or other forms of so-called transformation) and towards economic apportionment based on relative degrees of market value. If the First Amendment is going to function as a market (or value) allocation device, it is better to be clear and logical about how the defendant's expressive and economic interests ought to be weighed.

Under the current framework, by contrast, judges have been forced to grope for solutions that preserve otherwise inapposite rights behind the smoke screen of ill-fitting and misleading analyses. To that end, most jurisdictions ${ }^{13}$ have adopted some form of the transformative use test, which grants a complete defense where the defendant's otherwise infringing use is sufficiently "transformative."14 The very notion of transformation is suspect, and leading commentators regard the doctrine as particularly ambiguous and unhelpful. ${ }^{15}$ In theory, it protects uses that add "more than a 'merely trivial' variation." 16 In practice, it has forced judges to rationalize their holdings based on artistic evaluations, which are inherently unpredictable and arbitrary. ${ }^{17}$ Transformative meaning can be found anywhere with enough abstraction, and

12. Gopal SReenivasan, The Limits of Lockean Rights in Property 5 (1995) (discussing Locke's theory of property).

13. 2 J. THOMAS MCCARThy, The RIghts OF Publicity AND PRIVACY $\S \S 8: 71-$ $8: 72$ (2d ed. 2014) (describing other tests used to evaluate the right of publicity, including the Rogers test and the "predominant use" test).

14. Id. $\S 8: 72$.

15. Id. ("Difficulty of application and incertitude of result are the hallmarks of the court's 'transformative' test.").

16. Comedy III Prods., Inc. v. Gary Saderup, Inc., 21 P.3d 797, 810 (Cal. 2001) (quoting L. Batlin \& Son, Inc. v. Snyder, 536 F.2d 486, 490 (2d Cir. 1976)).

17. See infra Part III (analyzing several prominent right-of-publicity holdings). 
courts have resorted to interpreting subtext, metaphors, and social commentary as grounds for transformation. ${ }^{18}$

This Article argues that underneath the convoluted constitutional balancing is a simple and straightforward economic division. The issue we identify is that courts are too preoccupied with First Amendment baggage to honestly and effectively grapple with issues of allocation, more so because the First Amendment works an all-or-nothing result that is plainly incompatible with today's participatory and highly collaborative culture and the modern generation of remixers and recoders. ${ }^{19}$

The current state of the law contrives an artificial dichotomyproperty vs. speech 20 -in uses of celebrity images that plainly fails to accommodate reality. This oversimplified dichotomy will never resolve itself because the current rhetoric and rights talk masks the underlying competing issues at stake. We propose that the right of publicity be made more predictable and consistent by importing theories of compulsory licensing and economic apportionment.

The last decade has seen a marked increase in right-of-publicity litigation for a number of reasons. ${ }^{21}$ For one, the celebrity culture market itself continues to grow and mature. ${ }^{22}$ Americans are undeniably obsessed with the cult of fame, and many commentators argue that our obsession has reached unhealthy proportions..$^{23}$ Even President Barack Obama has observed and criticized this phenomenon (perhaps more telling is the overwhelming negative

18. See, e.g., Northland Family Planning Clinic, Inc. v. Ctr. for Bio-Ethical Reform, 868 F. Supp. 2d 962, 970 (C.D. Cal. 2012) ("Examples of fair use include social commentary, criticism, and news reporting.").

19. $C f$. LaWrence Lessig, Free Culture: The Nature and Future of CREATIVITY (2004) (describing the tensions between fair use and copyright). Lessig first acknowledges that "for at least the first 180 years of our Republic, [our tradition] guaranteed creators the right to build freely upon their past, and protected creators and innovators from either state or private control." Id. at 10. "Yet," Lessig notes, "the law's response to the Internet ... has massively increased the effective regulation of creativity in America. To build upon or critique the culture around us one must ask, Oliver Twist-like, for permission first[,] . . . [which] is not often granted to the critical or the independent." Id.

20. See J. Steven Bingman, Comment, A Descendible Right of Publicity: Has the Time Finally Come for a National Standard?, 17 PEPP. L. REV. 933, 967 (1990) (discussing the tension between the right of publicity and the First Amendment that courts must address).

21. Mark P. McKenna, The Right of Publicity and Autonomous SelfDefinition, 67 U. PITT. L. REv. 225, 226 (2005) (observing "a long line of (often successful) attempts by celebrities to extend the [right of publicity's] boundaries" and noting that "there is no end to that trend in sight").

22. See Mark Harris, Fame: A P\&L, N.Y. MAG. (Jan. 29, 2012), http://nymag.com/arts/all/celebrity-economy/fame-2012-2/.

23. Jo Piazza, Americans Have an Unhealthy Obsession with Celebrities, HuFfingTON POST (Mar. 28, 2012, 12:09 PM), http://www.huffingtonpost.com/jopiazza/americans-unhealthy-obsession-with-celebrities_b_1385405.html. 
response to said criticism). ${ }^{24}$ Many scholars and judges note that celebrities have become "shortcuts" 25 in expressive speech-their very persona taking on representational meaning. ${ }^{26}$

Second, new technology exists that allows individuals with little to no training to "rip, mix, and burn" digital imagery and create infringing mash-ups. ${ }^{27}$ In that vein, the state of the art allows for extremely accurate renderings and portrayals of celebrities that were never before possible. Finally, the digital economy has provided the infrastructure to allow even amateurs to readily monetize celebrity personas in the form of page views, advertising revenue, and interactive media, such as video games. ${ }^{28}$

In short, celebrity likenesses have become symbolic expressions, and artists are using those symbols to create speech that is readily commercialized. The wrinkle is that part of the expression (and the attendant profit) is plainly open to free use while the other is plainly property, forcing a judge to pick a side within a spectrum. Meanwhile, the judicial tests place undue weight on the factors of commercialism and realism, potentially understating the artistic value of celebrity identity as a speech commodity and punishing artists for integrating shared cultural symbols.

Our solution preserves the freedom to use a celebrity's likeness while also compensating the celebrity for that use. It erases the winner-take-all model that the jurisprudence has developed in favor of a more balanced approach that respects both the defendant's right to use cultural commons and the plaintiff's right to profit off of her image. Judges will no longer be forced to make unsatisfactory artistic evaluations on the merits of a creative work, which have led to so much vexation and consternation. Instead, the analysis shifts to value apportionment and away from strange theories about what is and what is not sufficiently expressive to justify free riding.

The first Part of this Article charts a brief course through the history of the right of publicity and the First Amendment. The second Part studies the competing economic rights, their

24. Marina Hyde, Criticising Kanye and Kim Kardashian? What Was Barack Obama Thinking?, THEGUARDIAN (Aug. 15, 2013, 1:31 PM), http://www.theguardian.com/lifeandstyle/lostinshowbiz/2013/aug/15/kanyewest-kim-kardashian-barack-obama.

25. See, e.g., Cardtoons, L.C. v. Major League Baseball Players Ass'n, 95 F.3d 959, 972 (10th Cir. 1996) ("Through their pervasive presence in the media, sports and entertainment celebrities come to symbolize certain ideas and values.").

26. See Jessica Litman, Breakfast with Batman: The Public Interest in the Advertising Age, 108 YALE L.J. 1717, 1725-29 (1999) (discussing celebrities as "trade symbols").

27. LESSIG, supra note 19, at 35-40 (2004) (discussing children using "free web stuff" and simple tools to "mix 'image, sound, and text" (citation omitted)).

28. Caitlin Burns, The Future Is Here and It Is Grumpy: The Monetization of Memes, TRANSMEDIA COALITION (Apr. 2, 2013), http://transmediacoalition.com /cburns/story/the-future-is-here-and-it-is-grumpy-the-monetization-of-memes. 
philosophical justifications, and their shortcomings. The third Part analyzes several major cases that dealt with the conflict of rights, criticizing the transformative use analysis as a proxy for economic value and explaining the shortfalls of the test. The fourth Part proposes a new theory of add-on value and a paid-for First Amendment.

\section{HISTORICAL OVERVIEW OF RIGHT-OF-PUBLICITY LAW}

The right of publicity grew from a modest personal privacy right into an extremely broad property tool that commoditizes and protects a celebrity's entire persona, including the use of lookalikes, ${ }^{29}$ soundalikes, ${ }^{30}$ catchphrases, ${ }^{31}$ and even robotic imitations. ${ }^{32}$ The contemporary right of publicity represents a property interest in the likeness of an individual and provides an enforcement mechanism to prevent unauthorized use of one's likeness. ${ }^{33}$ Yet for such a powerful right, its contours are woefully undefined because its common-law development varied from state to state, leaving some states much more favorable than others. ${ }^{34}$ This Part describes the evolution of the right of publicity from a limited personal right into a broad property right and highlights some of the conceptual challenges associated with the transition.

\section{A. From Personal Privacy Rights to Descendible Property Rights}

In 1890, Samuel Warren and Louis Brandeis published The Right to Privacy, ${ }^{35}$ a law review article that has taken on almost mythical status as "the most influential law review article ever

29. Cf. Allen v. Nat'l Video, Inc., 610 F. Supp. 612, 630 (S.D.N.Y. 1985) (declining to decide a right-to-publicity claim but enjoining celebrity lookalike under the Lanham Act).

30. Waits v. Frito-Lay, Inc., 978 F.2d 1093 (9th Cir. 1992) (affirming a verdict for the plaintiff celebrity in a "voice misappropriation" case), abrogated by Lexmark Int'l, Inc. v. Static Control Components, Inc., 134 S. Ct. 1377 (2014).

31. Carson v. Here's Johnny Portable Toilets, Inc., 698 F.2d 831, 836 (6th Cir. 1983) (holding that the plaintiff celebrity was "entitled to judgment" on a right-to-publicity claim regarding the misappropriation of the plaintiff's catchphrase).

32. White v. Samsung Elecs. Am., Inc., 971 F.2d 1395 (9th Cir. 1992).

33. See Kevin L. Vick \& Jean-Paul Jassy, Why a Federal Right of Publicity Statute Is Necessary, 28 COMM. LAW. 14, 14-15 (2011), available at http://www.americanbar.org/content/dam/aba/publications/communications_law yer/august2011/why_federal_right_publicity_statute_is_necessary_comm_law_2 8_2.authcheckdam.pdf (describing the development of the right of publicity into a property right).

34. Id. at 15 (observing that Indiana law is particularly favorable).

35. Samuel D. Warren \& Louis D. Brandeis, The Right to Privacy, 4 HaRV. L. REV. 193 (1890). 
written" and planted the seed for the right of publicity. ${ }^{36}$ In essence, Warren and Brandeis created a new right: "the right to be let alone." 37 This right was described as an extension of the current law, grounded in tort and copyright. ${ }^{38}$ Importantly, the authors specifically envisioned the right of privacy as a personal right, not as a property right. 39 The distinction is critical; personal rights are inalienable and cannot be transferred, descended, or inherited 40 -in short, they cannot be effectively monetized.

Thus, the right of publicity grew out of frustration with the personal nature of the right of privacy, but only after American culture underwent a substantial shift. ${ }^{41}$ In the early twentieth century, Americans were largely disaffected by the cult of fame.42 We can speculate as to reasons; perhaps individuals at large were more modest, mass media had not yet taken off, and there was substantial socioeconomic tension following the Great Depression.

Circuit Judge Sibley aptly summed up American attitudes towards fame in the 1935 Hanna Manufacturing Co. v. Hillerich \& Bradsby Co. ${ }^{43}$ decision. There, the plaintiff licensed and sold a line of baseball bats signed by famous players. ${ }^{44}$ The defendant, sensing ample opportunity for competition, marketed its own competing line of bats that featured player names as well.45 The plaintiff ultimately won an injunction on unfair competition grounds, but the court explicitly rejected its property-based right-of-privacy argument: "Fame is not merchandise. It would help neither sportsmanship nor business to uphold the sale of a famous name to the highest bidder as property." 46 This decision reflected the

36. Melville B. Nimmer, The Right of Publicity, 19 LAW \& CONTEMP. PROBS. 203, 203 (1954).

37. Warren \& Brandeis, supra note 35, at 193.

38. Id. at 211; accord McKenna, supra note 21, at 234.

39. Warren \& Brandeis, supra note 35 , at 213 ("[T]he principle which has been applied to protect these rights is in reality not the principle of private property, unless that word be used in an extended and unusual sense."); Diane Leenheer Zimmerman, Information as Speech, Information as Goods: Some Thoughts on Marketplaces and the Bill of Rights, 33 WM. \& MARY L. REV. 665, 699-700 (1992).

40. See, e.g., Reeves v. United Artists, 572 F. Supp. 1231, 1234 (N.D. Ohio 1983) ("The right of privacy is a personal right which terminates at death.").

41. Michael Madow, Private Ownership of Public Image: Popular Culture and Publicity Rights, 81 CALIF. L. REv. 125, 167 (1993).

42. Id. at 226 ("A century ago actors, entertainers, and athletes were still socially marginal and politically inconsequential.... [N]ot even the most celebrated stage performers were welcome in polite society ....").

43. 78 F.2d 763 (5th Cir. 1935).

44. Id. at 765 .

45. Id. at 766 .

46. Id. 
sentiment during the early twentieth century that fame was personal, inalienable, and not particularly valuable. 47

Such opinions were short-lived, though. In addition to the baby boom, America underwent a legal boom after the Second World War. ${ }^{48}$ Within a span of twenty-five years, the right of publicity was coined as a term, 49 classified as a property right,, 50 and legitimized by the Supreme Court.51 By the end of the 1970s, the right of publicity had transformed into a sabre as its growth mirrored the Hollywood boom. 52

\section{B. The Property Paradigm for the Right of Publicity}

Casting the right of publicity as a property right has had massive implications in the development of the law. Arguably, this one seemingly minor distinction is the engine that runs America's celebrity economy. Melville Nimmer is widely regarded as spearheading the property reformation with his 1954 article The Right of Publicity. ${ }^{53}$ By the time the Supreme Court took up the issue in 1977 , the right of publicity was well settled as a property right.

At the most basic level, a personal right cannot be assigned to others. Personal rights are inalienable, which substantially reduces their economic value. ${ }^{54}$ A corporation seeking to use an individual's

47. How would our law look if this reasoning was never overturned? One may be tempted to think that we would be inundated with knockoff baseball bats adorned with Barry Bonds's signature. Of course, this would not be the case because the Lanham Act (passed in 1946) includes provisions governing false endorsement and unfair competition. The Lanham (Trademark) Act, Pub. L. No. 79-489, § 43, 60 Stat. 427, 441 (1946) (codified as amended 15 U.S.C. § 1125 (2012)). The majority of effects would likely be "under the hood," modifying the way that corporations licensed likenesses by having to approach individuals individually. The only obvious change would be the imposition of a strict durational time limit, as the right of publicity would be personal to the individual and therefore expire along with the celebrity.

48. See Total National Lawyer Counts 1878-2013, ABA (2013), http://www.americanbar.org/content/dam/aba/administrative/market_research/t otal_national_lawyer_counts_1878_2013.authcheckdam.pdf.

49. Haelan Labs., Inc. v. Topps Chewing Gum, Inc., 202 F.2d 866, 868 (2d Cir. 1953) (coining the "right of publicity" term and creating an alienable right).

50. Nimmer, supra note 36 , at 216 . Courts were understandably reluctant to develop such a powerful right quickly, so the transition was a gradual one with piecemeal decisions over twenty years. Oren J. Warshavsky, The Expanding Right of Publicity, Metropolitan CorP. Couns., Feb. 2006, at 32, available at http://www.metrocorpcounsel.com/pdf/2006/February/32.pdf.

51. See Zacchini v. Scripps-Howard Broad. Co., 433 U.S. 562 (1977) (recognizing and upholding the right of publicity).

52. Stacey L. Dogan \& Mark A. Lemley, What the Right of Publicity Can Learn from Trademark Law, 58 STAN. L. REV. 1161, 1173 (2006).

53. Nimmer, supra note 36; see also Madow, supra note 41, at 148 (noting Nimmer's "seminal 1954 article").

54. See, e.g., Morrison v. State, 252 S.W.2d 97, 101 (Mo. Ct. App. 1952) ("Inalienable is defined as incapable of being transferred."); Erin Ryan, 
likeness to market a product would essentially receive a release from liability instead of an independently enforceable property right. This seems like a minor difference, but in practice it would allow a competitor to outbid the original licensor for the same likeness. The original licensor might have a breach-of-contract claim against the celebrity, but would have little to no other recourse (apart from potential Lanham Act claims). ${ }^{55}$

Second, a personal right is non-descendible, thus expiring along with the individual. ${ }^{56}$ If the right of publicity had remained personal, then celebrity likenesses would enter the public domain upon death, and we would all be free to dress up as Elvis and sing like the King. ${ }^{57}$ But the duration of a descendible property right in one's likeness is much more complicated and has been described by Professor McCarthy as "by nature almost arbitrary."58 In 2012, a California district court applying New Jersey law held that "[a]n 'almost arbitrary' ruling is unacceptable" and then arbitrarily set the duration at fifty years. ${ }^{59}$ In contrast, the California postmortem duration is seventy years, the same as copyright.60 And yet in Tennessee, the duration is more like trademark and can potentially last forever. ${ }^{61}$

Third, a personal right cannot exist for a nonperson. ${ }^{62}$ Nimmer conceptualized this issue as denying the right of publicity to famous animals such as the dog $\operatorname{Lassie}^{63}$ (or modernly, Grumpy Cat). ${ }^{64}$

Federalism at the Cathedral: Property Rules, Liability Rules, and Inalienability Rules in Tenth Amendment Infrastructure, 81 U. CoLO. L. REV. 1, 18 (2010) (" $[T]$ he problem with inalienability rules is that they prioritize other policy concerns over economic efficiency ....").

55. See Lanham Act, 15 U.S.C. $\S \S 1051-1141 n$ (2012).

56. Bingman, supra note 20 , at 936 ("[T] $\mathrm{T}]$ he right of publicity is a personal right and extinguishes upon the death of the person.").

57. We would advise against dressing up like Elvis and singing his songs without consent. Estate of Presley v. Russen, 513 F. Supp. 1339 (D.N.J. 1981) (holding that an Elvis impersonator's act lacked independent creative components and was not protected by the First Amendment).

58. MCCARTHY, supra note 13, §9:16.

59. Hebrew Univ. of Jerusalem v. Gen. Motors LLC, 903 F. Supp. 2d 932, 934, 942 (C.D. Cal. 2012) (quoting MCCARTHY, supra note 13, § 9:16).

60. Compare CAL. CIV. CoDE $§ 3344.1$ (g) (Deering 2014), with 17 U.S.C. $\S$ 302(a) (2012).

61. TENN. CODE ANN. § 47-25-1104(b)(2) (2013) ("The exclusive right to commercial exploitation of the property rights is terminated by proof of the nonuse of the name, likeness, or image of any individual for commercial purposes by an executor, assignee, heir, or devisee to such use for a period of two (2) years subsequent to the initial ten (10) year period following the individual's death.").

62. Nimmer, supra note 36 , at 210 .

63. Id.

64. Katie Van Syckle, Grumpy Cat, N.Y. MaG. (Sept. 29, 2013), http://nymag.com/news/business/boom-brands/grumpy-cat-ben-lashes-2013-10/ (describing how Grumpy Cat, Ltd., a corporation formed to monetize a cat with 
Humorous as it may be, serious dollars are at risk here, 65 and several active lawsuits are pending. 66 Many of the Internet's favorite pets have their own managers, and their YouTube sites have enough viewers generating ad revenue that their owners have been able to retire. 67

Setting aside animals, there is another major issue regarding videogame "persons." There are dozens, perhaps hundreds, of multimillion dollar videogame franchises that rely on fictional likenesses. One videogame hero became so popular that he was immortalized as a wax figure at Madame Toussauds. ${ }^{68}$ Based on Lockean principles underlying the right of publicity, it would seem natural to extend the rights to fictional video game celebrities because so much labor goes into their development and marketing. Beyond that, the other bodies of intellectual property law, copyright and trademark, are ill suited to adequately protect fictional characters.69 But, as demonstrated by the recent NCAA dispute, videogames have provided a particularly contested battleground for the right of publicity. ${ }^{70}$

\section{JUSTIFICATIONS FOR A PROPERTY RIGHT}

Courts and commentators have debated justifications for the property interest in publicity since it was first given legal life. Yet, no one theory ever seems sufficient to cover the entire breadth of the

a frowning face, is "a seven-figure franchise" and that Grumpy Cat is "just another pop-culture personality to be branded and marketed").

65. Rebecca Keegan, Grumpy Cat Gets a Movie Deal, L.A. Times (May 30, 2013), http://articles.latimes.com/2013/may/30/entertainment/la-et-mn-grumpycat-movie-20130530 ("[Broken Road Productions recently] optioned the rights to make a film based on Grumpy Cat's persona.").

66. See, e.g., Ryan W. Neal, WB Cat Fight: Nyan Cat, Keyboard Cat Sue Warner Bros for Copyright and Trademark Infringement, INT'L BUS. TIMES (May 3, 2013, 12:18 PM), http://www.ibtimes.com/wb-cat-fight-nyan-cat-keyboard-catsue-warner-bros-copyright-trademark-infringement-1235981 (explaining a copyright infringement action over the unauthorized use of "Keyboard Cat").

67. See Some Pets Make Big Money for Their Owners, Inside EdiTION (Apr. $30,2013)$, http://www.insideedition.com/headlines/6247-some-pets-make-bigmoney-for-their-owners.

68. Master Chief, MADAME Tussauds, http://www.madametussauds.com /hollywood/ourfigures/moviecharacters/masterchief.aspx (last visited July 29, 2014) (noting that Master Chief, the player-character of the multi-million dollar $\mathrm{X}-\mathrm{Box}$ and $\mathrm{PC}$ Halo videogame franchise, is "the first video game character immortalized by Madame Tussauds").

69. J. C. Sander, The End of Arbitrary Findings of Secondary Meaning: A Call for the Expansion of Trademark Status of Literary Characters, 17 INTELL. PROP. L. BULL. 1 (2013) (discussing copyright and trademark protection for fictional characters).

70. See infra Subpart III.D. 
right. ${ }^{71}$ As a result, courts often mix up several justifications in order to paste together a compelling justification to carry their decision. This imprecise practice has led to some anxiety over the power of the right, particularly when it rubs up against the First Amendment. ${ }^{72}$

\section{A. Natural Rights Theory}

At one end of the spectrum are the natural-rights theorists. In general, natural rights are considered so self-evident and inherent that they need no justification or authorization by law. ${ }^{73}$ In American law, we hold some truths to be "self-evident," such as the right to "life, liberty, and the pursuit of happiness." 74 The natural rights rationale for the right of publicity "recognizes that a person should inherently be able to financially benefit when another uses his or her identifiable persona for ... commercial benefit." 75

The right to privacy, which is the foundation of the right of publicity, is premised on a natural-rights approach. ${ }^{76}$ Brandeis and Warren felt that the right to be let alone was "a part of the more general right to the immunity of the person." 77 Furthermore, they actually considered and ultimately rejected a labor-based justification. ${ }^{78}$ They did so because they theorized that it would essentially undercut existing intellectual property regimes, fearing that the court would discover it was much more laborious to "conduct one's self properly in business and in domestic relations ... than that involved in painting a picture or writing a book."79

In essence, they felt that the labor justification would be a copout because it is impossible to quantify time spent on "conduct[ing]

71. Restatement (ThiRd) of Unfair Competition $\S 46 \mathrm{cmt}$. c (1995) ("The rationales underlying the recognition of a right of publicity are generally less compelling than those that justify rights in trademarks or trade secrets.").

72. Martin Luther King, Jr., Ctr. for Soc. Change, Inc. v. Am. Heritage Prods., Inc., 296 S.E.2d 697, 708 (Ga. 1982) (Weltner, J., concurring) ("[I]n proclaiming this new 'right of publicity,' we have created an open-ended and illdefined force which jeopardizes a right of unquestioned authenticity-free speech.").

73. Murray N. Rothbard, The Ethics of Liberty 23 (2002).

74. THE DECLARATION OF INDEPENDENCE para. 2 (U.S. 1776).

75. MCCARTHY, supra note $13, \S 2: 2$.

76. Pavesich v. New England Life Ins. Co., 50 S.E. 68, 68 (Ga. 1905) ("A right of privacy is derived from natural law, recognized by municipal law, and its existence can be inferred from expressions used by commentators and writers on the law as well as judges in decided cases."); Warren \& Brandeis, supra note 35, at 205 (explaining that the right of privacy is analogous to the right not to be assaulted or beaten, which are classic examples of natural rights representing bodily integrity).

77. Warren \& Brandeis, supra note 35 , at 207.

78. Id.

79. Id. 
one's self properly." 80 When an artist paints a painting, she can point to a finite amount of hours spent with brush in hand; likewise, a writer can tally her hours at the keyboard. In contrast, how does one measure the hours spent living a respectful life? This is why they opted for a natural-rights approach.

However attractive the natural-rights approach may be, modern commentators "generally shy away from directly endorsing a 'natural law' recognition of a right of publicity.... [T] he Tenth Circuit refused to consider the possibility ...."81 The natural rights jurisprudence fell out of favor over the twentieth century as more advanced theories such as critical legal studies and legal realism rose in popularity. 82 In the face of heightened scrutiny, the courts turned to a theory they knew well and adopted it as if it were selfevident.

\section{B. Lockean Labor Theory}

Lockean labor theory is the workhorse of intellectual property law ${ }^{83}$ and is supported by influential commentators including McCarthy ${ }^{84}$ and Nimmer. ${ }^{85}$ Oftentimes, Locke is combined with the natural-rights theorists, but there are minor differences worthy of splitting them apart. Under a traditional natural-rights approach, rights inure just by the nature of being a person-one need not perform any labor to enjoy the right to bodily integrity. ${ }^{86}$ In contrast, Lockean labor theory requires an expenditure of directed labor in order to obtain a property right: "[W] hat I create is mine." 87 Thus, the premise of Lockean labor theory, and also its weakness, is an emphasis on personal creation.

Proponents of this justification argue that celebrities work to achieve their fame and are therefore entitled to reap the benefits of that labor in the form of a marketable property right. 88 This theory

80. Id.

81. MCCARTHY, supra note $13, \S 2: 2$.

82. See generally G. Edward White, From Realism to Critical Legal Studies: A Truncated Intellectual History, 40 Sw. L.J. 819 (1986) (discussing legal realism and critical legal studies in the twentieth century).

83. Zimmerman, supra note 39, at 676-77 (describing Locke's "lasting influence" within intellectual property); accord Alice Haemmerli, Whose Who? The Case for a Kantian Right of Publicity, 49 DuKE L.J. 383, 388 (1999) ("Both proponents and critics of the right of publicity generally perceive it as a property claim grounded in Lockean labor theory.").

84. MCCARTHY, supra note $13, \S 2: 5$ (describing the Lockean labor theory approach as "perceptive and courageous").

85. Nimmer, supra note 36, at 216 ("It would seem to be a first principle of Anglo-American jurisprudence, an axiom of the most fundamental nature, that every person is entitled to the fruit of his labors unless there are important countervailing public policy considerations.").

86. See supra Subpart II.A.

87. MCCARTHY, supra note $13, \S 2: 5$.

88. Id. 
is probably the closest to reflecting reality but is far too enamored with the myth of celebrity self-creation to function as an adequate justification for such a sweeping, exclusive right of control. "The notion that a star's public image is nothing else than congealed star labor is just the folklore of celebrity, the bedtime story the celebrity industry prefers to tell us and, perhaps, itself." 89

The peculiar shortcoming of Lockean labor theory is that it generally is seen as a one-sided equation: individual + work $=$ fame . But the reality is that fame is a two-way street-it is relational and requires buy-in from the public at large; without the public investing at least their attention, a celebrity could hardly be called a celebrity..$^{90}$ No matter how it is interpreted, the public participates and expends labor to generate stardom just as much as the fortunate celebrity.

A celebrity, in short, does not make her public image, her meaning for others, in anything like the way a carpenter makes a chair from a block of wood. She is not the sole and sovereign "author" of what she means for others. Contingency cannot be entirely erased.... And because she cannot say [that she is solely responsible], she cannot lay a convincing moral claim to the exclusive ownership or control of the economic values that attach to it. 91

The Lockean labor theory is a tempting one. It indulges American mythologies and ideals of self-creation through work. It is widely accepted as a justification in other fields of intellectual property law. But there are nagging shortcomings and cracks that keep the theory from offering a complete justification. Principally, Brandeis and Warren refused to adopt a labor theory for the right of privacy because they felt it was impossible to measure the labor of conducting one's life. ${ }^{92}$ On top of that, fame is a relational phenomenon and requires participation by others to manifest. Finally, Lockean labor theory is largely regarded as a merit-based approach to property, but "[f]ame does not play fair; it plays favorites." ${ }^{3}$ However close Hollywood gets to transforming celebrity into a science, ${ }^{94}$ it will always be fickle and unpredictable to some degree and therefore incongruous to convey the entire bundle of sticks to the celebrity when their labor investment is tenuous at best. ${ }^{95}$

89. Madow, supra note 41 , at 184 .

90. Id. at 188 .

91. Id. at 195-96.

92. Warren \& Brandeis, supra note 35 , at 207.

93. Madow, supra note 41, at 189.

94. See id. at 189-91 (describing how the media has a "powerful institutional need" for celebrities and works to produce them).

95. Id. at $188-89$. 


\section{Incentive Theory}

The incentive theory is a particularly attractive justification for the right of publicity because it has a constitutional pedigree in the Progress Clause..$^{96}$ In essence, this theory justifies the right of publicity as a necessary incentive to entice individuals into becoming celebrities. ${ }^{97}$ The idea is that without a property right in publicity, individuals would have no economic reason to become famous because they could not effectively monetize their fame.

As specious as this argument may sound, it is one of the most prevalent and judicially recognized justifications. ${ }^{98}$ The Supreme Court cited to the incentive theory in Zacchini v. Scripps-Howard Broadcasting Co.99 as a justification for Ohio's particular right-ofpublicity law. ${ }^{100}$ Likewise, the California Supreme Court also endorsed the incentive theory. 101 Undoubtedly, the connection to the Constitution gives this theory substantial gravitas. Yet it makes several assumptions that are suspect at best and outdated at least.

First, the incentive theory requires a baseline assumption that individuals do not innately desire fame, and thus our legal system must incentivize the pursuit of fame through a property right. While there may have been support for this assumption in the early twentieth century, it is plainly contradicted by modern experience. A recent UCLA study found that "becoming famous is the major aspiration of children from 10-12 years of age."102 Any actual effect of incentive in the form of a legal property right is speculative at best. ${ }^{103}$

96. U.S. Const. art. I, $\S 8$, cl. 8 ("[The Congress shall have Power] [t]o promote the Progress of Science and useful Arts, by securing for limited Times to Authors and Inventors the exclusive Right to their respective Writings and Discoveries.").

97. Zacchini v. Scripps-Howard Broad. Co., 433 U.S. 562, 576 (1977).

98. MCCARTHY, supra note $13, \S 2: 6$ ("[C]ertain persons should be given an economic incentive to undertake socially useful or enriching activities and thereby enter the public eye. ... This is the rationale most often given in the case law.").

99. 433 U.S. 562.

100. Id. at 576 ("[T] he protection provides an economic incentive for him to make the investment required to produce a performance of interest to the public. This same consideration underlies the patent and copyright laws long enforced by this Court.").

101. Comedy III Prods., Inc. v. Gary Saderup, Inc., 21 P.3d 797, 805 (Cal. 2001) ("In sum, society may recognize, as the Legislature has done here, that a celebrity's heirs and assigns have a legitimate protectible interest in exploiting the value to be obtained from merchandising the celebrity's image, whether that interest be conceived as a kind of natural property right or as an incentive for encouraging creative work.").

102. Yalda T. Uhls \& Patricia M. Greenfield, The Value of Fame: Preadolescent Perceptions of Popular Media and Their Relationship to Future Aspirations, 48 DevelopmenTAL PSYCHOL. 315, 315 (2012).

103. Zimmerman, supra note 39 , at 703-12 (criticizing the incentive theory). 
Second, it assumes that fame and celebrity status is not a sufficient reward in and of itself. This assumption also had a lot of support in the early twentieth century, but as mass culture developed through the latter half of the twentieth century into the well-oiled machine it is today, the assumptions are obviously outdated.104 Two of the circuits that rejected the incentive theory did so in part because they felt that fame was its own reward since it represented some measure of underlying success for which the celebrity was already compensated and also enhanced endorsement deals. ${ }^{105}$

Third, the incentive theory fails to justify the application of the right of publicity to "ordinary" people whose images are taken and exploited or who are, by chance victims of fate, catapulted into celebrity status ${ }^{106}$ (e.g., Capt. Sully Sullenberger ${ }^{107}$ ). Despite the incentive theory's shortcomings, it maintains a lofty status due largely to its constitutional roots. The Progress Clause makes intuitive sense as a socially beneficially device because it is designed to encourage the "Science and useful Arts."108

In conclusion, all of the foregoing theories fail to completely encompass a satisfactory justification for the right of publicity as a property right. Each theory has its merits, but no one theory can accommodate the modern right's sheer breadth. And for that reason many courts tend to borrow a little bit from column A and a little bit from column $B$ in order to keep the right from collapsing under its own weight. When courts have to resort to such a patchwork, it makes litigation and prediction extremely challenging. Without a clear, singular justification, the boundaries of the right become

104. Madow, supra note 41 , at 171-72 (describing how fame developed into a commodity asset).

105. Cardtoons, L.C. v. Major League Baseball Players Ass'n, 95 F.3d 959, 974 (10th Cir. 1996) ("[T] he additional inducement for achievement produced by publicity rights are often inconsequential because most celebrities with valuable commercial identities are already handsomely compensated."); accord C.B.C. Distribution \& Mktg., Inc. v. Major League Baseball Advanced Media, L.P., 505 F.3d 818, 824 (8th Cir. 2007) ("[P]layers are rewarded, and handsomely, too, for their participation in games and can earn additional large sums from endorsements and sponsorship arrangements."). But see MCCARTHY, supra note $13, \S 2: 6$ ("The rejection of the incentive justification ... [is] a bizarre form of judicial income redistribution between professional athletes and those in the business of selling products and services that use the athlete's identities and accomplishments. I cannot see how judges can or should make a moral or legal judgment as to which of those two groups is more entitled to the economic value of the fame and accomplishments of professional athletes.").

106. McKenna, supra note 21 , at 252-53.

107. Captain Sullenberger famously landed a disabled commercial airliner in the Hudson. Since then he has published several books, been featured on television multiple times, and is a motivational speaker. See Chelsey B. "Sully" Sullenberger, III, SULly SULLENBERGER, http://sullysullenberger.com/\#/about (last visited July 30,2014 ).

108. U.S. CONST. art. I, § 8, cl. 8. 
impossible to measure with the degree of certainty necessary for businesses and individuals to delineate legal and infringing uses.

\section{Free and Less Free Speech}

The First Amendment freedom of speech is often lauded as a "blueprint for personal freedom and the hallmark of an open society."109 The Founding Fathers developed the Free Speech Clause as an anticensorship mechanism in response to the British Crown instituting aggressive publication regulations. ${ }^{110}$ But, interestingly, issues regarding copyright and patent law spurred a robust legal development as those bodies of law rapidly evolved, while the free speech doctrine lay relatively dormant.111 Worse yet, intellectual property law expanded on a largely independent track "even [as] portions of the public common were knowingly or inadvertently fenced off in the process." 112

For the most part, the law operated on an assumption of free speech, while different intellectual property regimes chipped away and carved out discrete compartments of speech-property ownership.113 Judges were comfortable assigning out specifically delineated property rights based on the Lockean justification.114 But the reward generally had defined scope and time limits. ${ }^{115}$ This tradeoff tacitly respected the spirit of the Free Speech Clause, even if it removed some speech from the public domain.

The ultimate conclusion is that the First Amendment offers "no talismanic power to prevent incursions by property law."116 The historical trend has been to expand property rights, 117 and if one views it as a zero-sum game, it indicates that the realm of available free speech is shrinking. Furthermore, it is extremely unlikely that we will observe a reversal of this trend. Thus, at some point, the Supreme Court will have to face the issue and modify the law to prevent censorship while compensating the property ownership. When the issue is inevitably raised, the prudent solution is a

109. About the First Amendment, FIRst AMENDMENT CENTER, http://www.firstamendmentcenter.org/about-the-first-amendment (last visited July 30,2014$)$.

110. Zimmerman, supra note 39 , at $677-78$.

111. Id. at 685 .

112. Id. at 703 .

113. See id. at 678-79 (discussing early scholarly development of the concept of free speech that did not contemplate related "economic or contractual transactions").

114. Id. at 712 .

115. See 17 U.S.C. $\S \S 302-305$ (2012) (setting forth copyright duration); 35 U.S.C. $\S 154$ (2012) (setting forth patent duration).

116. Zimmerman, supra note 39 , at 739 .

117. LESSIG, supra note 19, at 83-99 (describing the expansion of copyright duration and scope throughout history). 
compulsory license. This scheme preserves the basic premise of free communication of ideas while also respecting the property right.

\section{E. Shared Cultural Resources and Participatory Culture}

Celebrity likenesses can sometimes transcend their conventional roles and become ideas in and of themselves. These ideas can take on short form for language and thus become the very means of communication for certain groups. But the right of publicity can interfere and stifle the conversation. Celebrities become known for their conduct: charity, greed, naivety, experience, etc. And because celebrities occupy such a significant portion of popular culture, their constant presence becomes a point of shared, mutual experience. Thus, celebrity likenesses are shortcuts to interaction by way of association. Courts have even taken explicit notice of the phenomenon and carved out exceptions. ${ }^{118}$

To a large extent, modern culture has gone online, which has far reaching consequences for intellectual property law, especially the right of publicity. The Internet breaks down borders and allows participation and interaction (and infringement) on a massive scale. YouTube users watch over six billion hours of footage each month. ${ }^{119}$ Beyond that, high-traffic social websites such as Facebook, 120 Twitter, ${ }^{121}$ reddit, ${ }^{122}$ imgur, ${ }^{123}$ and tumblr ${ }^{124}$ allow users to post, discuss, and create content individually or collaboratively. Modern participatory culture is anchored on the Internet where content can be created, uploaded, shared, and remixed at the push of a button..$^{125}$

Many content trends involve "memes," 126 which pose innovative intellectual property problems. ${ }^{127}$ Generally, memes are messages

118. See, e.g., Cardtoons, L.C. v. Major League Baseball Players Ass'n, 95 F.3d 959, 972 (10th Cir. 1996) ("Because celebrities are an important part of our public vocabulary, a parody of a celebrity does not merely lampoon the celebrity, but exposes the weakness of the idea or value that the celebrity symbolizes in society.").

119. Statistics, YouTuBE, https://www.youtube.com/yt/press/statistics.html (last visited July 30, 2014) (noting also over a billion unique users per month).

120. About, FACEBOOK, https://www.facebook.com/facebook/info (last visited July 30, 2014) (noting that Facebook has over a billion active users).

121. About, TwITTER, https://about.twitter.com/company (last visited July 30 , 2014) (noting that Twitter has 271 million monthly active users).

122. About Reddit, REDDIT, http://www.reddit.com/about/ (last visited July 30,2014 ) (noting that reddit receives over 100 million unique visitors each month).

123. About Imgur, IMGUR, http://help.imgur.com/hc/en-us/categories /200124526-About-Imgur (last visited July 30, 2014).

124. About tumblr, TUMBLR, http://www.tumblr.com/about (last visited July 30,2014 ) (noting that tumblr hosts almost 200 million blogs).

125. LESSIG, supra note 19 , at 38.

126. See Richard DawkIns, The Selfish Gene 206 (1976) (coining the term "meme" and defining it as "a unit of cultural transmission").

127. Austin Considine, Copycats, Takedowns, and Ass Rainbows: What Does Copyright Mean for Internet Memes?, VICE (Dec. 7, 2012, $11: 26$ AM), 
conveyed in the form of a picture transposed with captions. ${ }^{128}$ A type of visual communication, the image as a whole oftentimes has a satirical meaning that its component parts lack. Usually, a picture of a person or celebrity is used, or it could be a well-known trademark, logo, or brand, thus implicating other intellectual property rights.129 From Barack Obama to Miley Cyrus, many celebrities have appeared on some sort of meme.130

When a celebrity commits to a specific persona, cultural groups may seize on the shared cultural short form and use it. These celebrity personas are prime fodder for expression because they deliver a well-known meaning on one level already. Recoders take celebrity likenesses of social prototypes and subvert them as social commentary. ${ }^{131}$ One of the incredible facets of this kind of cultural generation is that it is extremely participatory; the online platforms provide tools to rapidly disseminate individual creations to large groups. A popular meme that can capitalize on a combination of clever creativity and celebrity personality can be seen by hundreds of millions practically overnight.

Memes are not only prized marketing assets, ${ }^{132}$ but they can also have lasting impacts on culture and the economy. For example, the "Doge" meme (a picture of a Shiba Inu dog with comical captions) became the branding icon for the "cryptocurrency" competitor to Bitcoin and is appropriately titled "Dogecoin."133 At first blush, it may seem like a joke, but Dogecoin crowdsourcing efforts based on reddit funded the 2014 Winter Olympic Jamaican bobsled team ${ }^{134}$ and a NASCAR team. ${ }^{135}$

http://motherboard.vice.com/blog/copycats-takedowns-and-ass-rainbows-whatdoes-copyright-mean-for-internet-memes.

128. Jorge R. Roig, Decoding First Amendment Coverage of Computer Source Code in the Age of YouTube, Facebook, and the Arab Spring, 68 N.Y.U. ANN. SuRV. AM. L. 319, 387-88 (2012).

129. Andy Goldstein, Technology: Internet Memes Pose Legal Questions, INSIDE CoUNS. (June 21, 2013), http://www.insidecounsel.com/2013/06/21 /technology-internet-memes-pose-legal-questions.

130. For an example of celebrity memes, see Celebrity Memes: The Funniest and Most Viral Internet Phenoms of 2013, Us WKLY.,

http://www.usmagazine.com/entertainment/pictures/celebrity-memes-the-

funniest-and-most-viral-internet-phenoms-of-2013-20131312/34568 (last visited July 30,2014$)$.

131. Madow, supra note 41, at 140-45.

132 Considine, supra note 127 (describing how Kohl's, Blizzard Entertainment, Wonderful Pistachios, and other companies ran meme-based ads).

133. Paul Vigna, BitBeat: Much Good, Dogecoin; So Hip, Wall ST. J. MONEYBEAT (Mar. 13, 2014, 4:26 PM), http://blogs.wsj.com/moneybeat /2014/03/13/bitbeat-much-good-dogecoin-so-hip.

134. Alex Hern, It's Bobsleigh Time: Jamaican Team Raises $\$ 25,000$ in Dogecoin, THEGUARDIAN (Jan. 20, 2014, 10:01 AM), http://www.theguardian.com /technology/2014/jan/20/jamaican-bobsled-team-raises-dogecoin-winterolympics. 
Furthermore, the influence of the law is extremely powerful in this area, and new detection technology is advanced.136 Kanye West was able to detect, notify, and shut down start-up cryptocurrency "Coinye" based on, among other claims, his right of publicity. 137 And, "Koindashian," an alternative digital currency that was available for a time after the discontinuation of Coinye, was shut down as well. 138

The central theme is that as our culture shifts towards online interaction, the right of publicity has the potential to become a powerful censoring mechanism ${ }^{139}$ by shutting down speech that capitalizes on or criticizes the symbolic meaning of different celebrities. ${ }^{140}$ From Arnold Schwarzenegger to Justin Bieber, each celebrity persona evokes a different image and a host of associations, positive and negative. It is in this context that the right of publicity and the First Amendment will have the most clashes and a compelling reason to proactively work to adapt the legal framework to avoid chilling effects on speech.

\section{Keystone Cases that Demonstrate How CouRts Use the RIGHT OF PUBLICITY AS A PROXY FOR ADD-ON VALUE}

For our purposes it is necessary to open up the hood and see how courts have dealt with the right of publicity and the First Amendment in order to assess the damage and provide a remedy. A large body of legal machinery has been fabricated to insulate the right of publicity from the First Amendment. In so doing, the courts have effectively manufactured patterns that fit their immediate case facts but fail to interact and mesh with a larger design. When elements are taken out of one case and applied to another, they rarely produce the same result. This Part attempts to diagram the application of the transformative use test-the principal test used to separate First Amendment speech from infringing speech. ${ }^{141}$

135. Larry Frum, Reddit, Dogecoin Support NASCAR Racer at Talladega, CNN (Apr. 24, 2014, 3:51 PM), http://www.cnn.com/2014/04/24/tech/web/nascar. dogecoin-talladega.

136. Considine, supra note 127.

137. Cyrus Farivar, Coinye Is Dead, Long Live Coinye: Kanye West Lawsuit Prompts Disarray, ARS TECHNICA (Jan. 14, 2014, 7:50 PM), $\mathrm{http}$ ://arstechnica.com/tech-policy/2014/01/coinye-is-dead-long-live-coinyekanye-west-lawsuit-prompts-disarray/.

138. Devnullius, Comment to Altcoins Which Are Dead. Or Not?, SamkeR's COMPUTER F. (June 13, 2014, 9:22 AM), http://scforum.info/index.php?topic $=9167.0$.

139. Madow, supra note 41 , at 138 ("[P]ublicity rights facilitate private censorship of popular culture.").

140. Cf. LESSIG, supra note 19 , at 100-05 (discussing the difficulties that creators of derivative works can have "clearing rights").

141. See generally Michael D. Murray, What Is Transformative? An Explanatory Synthesis of the Convergence of Transformation and Predominant Purpose in Copyright Fair Use Law, 11 CHI.-KENT J. INTELL. PROP. 260 (2012). 
Transformative use in the right-of-publicity context has had a relatively limited lifetime, first applied in 2001 by the California Supreme Court in Comedy III Productions, Inc. v. Gary Saderup, Inc. ${ }^{142}$ When stripped of its constitutional trappings, the transformative use test is simply a proxy for add-on value. The California Supreme Court held that a transformative use of a celebrity likeness is worthy of First Amendment protection because it is less likely to interfere with the economic interest protected by the right of publicity. ${ }^{143}$ The problem, as it will be traced through the case law, is that the test must measure artistic merit in order to reach a decision on economic distribution. ${ }^{144}$

This Part will trace a path through the relatively recent right. of-publicity jurisprudence. The goal is to show how the courts have taken conflicting approaches to fact patterns in order to rationalize the right of publicity and the First Amendment defense. First up is the California Supreme Court's decision in Comedy III, which imported the transformative use standard from copyright law. Next, the decision is compared to the Southern District of New York District Court's use of the predominant purpose test in Hoepker $v$. Kruger. ${ }^{145}$ After that, California's application of the transformative test will be contrasted against the Sixth Circuit's decision in ETW Corp. v. Jireh Publishing, Inc. ${ }^{146}$ Finally, several videogame cases, including Kirby $v$. Sega of America, Inc. ${ }^{147}$ and No Doubt $v$. Activision Publishing, Inc., 148 and the NCAA cases of Hart $v$. Electronic Arts, Inc. (Hart II) ${ }^{149}$ and In re NCAA Student-Athlete Name \& Likeness Licensing Litigation (Keller) ${ }^{150}$ will be analyzed to illustrate the application of transformative use in the videogame context.

\section{A. Comedy III and the Foundation of Transformative Use}

From the very beginning, the transformative use test has been fraught with analytical problems, unpredictable outcomes, and ambiguity. ${ }^{151}$ Borrowed from copyright law, transformative use is one of the factors of the fair-use analysis. It asks whether the defendant has "contribute[d] something more than a 'merely trivial'

142. 21 P.3d 797 (Cal. 2001).

143. Id. at 808 .

144. See id. at 809 ("We ask, in other words, whether a product containing a celebrity's likeness is so transformed that it has become primarily the defendant's own expression .....").

145. 200 F. Supp. 2d 340 (S.D.N.Y. 2002).

146. 332 F.3d 915 (6th Cir. 2003).

147. 50 Cal. Rptr. $3 d 607$ (Ct. App. 2006).

148. 122 Cal. Rptr. 3d 397 (Ct. App. 2011).

149. 717 F.3d 141 (3d Cir. 2013).

150. 724 F.3d 1268 (9th Cir. 2013).

151. MCCARTHY, supra note 13, $\S 8: 72$ (discussing cases using the transformative use test). 
variation" and thereby transformed the property of the plaintiff into "something recognizably "his own." 152 Ultimately, the test attempts to sort expressive and creative works into two boxes: a work is either transformative or it is not. And many commentators have rightly criticized the test as creating a false dichotomy. ${ }^{153}$ Nonetheless, courts have taken the test and expanded it with an oftentimes confusing and inconsistent logic.

The California Supreme Court first applied the test in Comedy III. There, an artist created a charcoal sketch of the Three Stooges with stunning realism and sold plain t-shirts adorned with the sketch for financial gain. ${ }^{154}$ The court held that this use was not transformative because the artist had not added any creative expression worthy of First Amendment protection and that the artist was essentially infringing on the property right by utilizing "conventional, more or less fungible, images of the celebrity."155

The key words here, conventional and fungible, shed light on the court's analysis and the spirit of the transformative use test. Fungibles are mutually interchangeable goods (e.g., money). ${ }^{156} \mathrm{~A}$ ten-dollar bill has the same value as any other ten-dollar bill, even though each bill is physically unique. In contrast, non-fungibles have individualized values, ${ }^{157}$ the classic example being an individual work of art.

In this way, the court is attempting to discriminate between protected First Amendment creative expression (non-fungible) and unprotected infringement (fungible). The conventional, fungible image of a celebrity must remain the property right of that celebrity. Indeed, the court concluded that it was concerned with who can produce and profit from a conventional celebrity image. ${ }^{158}$ The rationale for the distinction presumably is that these fungible products ostensibly require less creativity and therefore are less deserving of First Amendment protection.

One problem many First Amendment scholars have with this analysis, and the argument advanced by defendant Gary Saderup in Comedy III, is that an artistic portrait of a celebrity, however realistic, is nonetheless a drawing and thus a unique work of art

152. Comedy III Prods., Inc. v. Gary Saderup, Inc., 21 P.3d 797, 810 (Cal. 2001) (quoting L. Batlin \& Son, Inc. v. Snyder, 536 F.2d 486, 490 (2d Cir. 1976)).

153. See, e.g., MCCARTHY, supra note $13, \S 8: 72$ ("Any such rigid two-part dichotomy is divorced from the reality of the creative process.").

154. Comedy III, 21 P.3d at 800-01.

155. Id. at 808 .

156. WebSTER's THIRD NEW INTERNATIONAL DiCTIONARY 922 (1981).

157. Non-Fungibles Definition, Fin. InVESTMENT Bus. Glossary, http://www.finance-investment-business-glossary.com/definitions/non

_fungibles.shtml (last visited Aug. 3, 2014).

158. Comedy III, 21 P.3d at 811. 
that cannot be considered fungible or conventional.159 The argument is along the lines of no two drawings are identical-each artist makes unique, creative decisions regarding line curvature, shading, positioning, etc.-thus the drawing of a celebrity, however realistic, is creative expression worthy of protection. ${ }^{160}$ For these critics, only a mechanical reproduction of the celebrity likeness, such as a photograph of the Three Stooges, would fail the transformative use test.

This interpretation certainly appeals to First Amendment proponents, and the California Supreme Court acknowledged its merits. ${ }^{161}$ But the court needed to find something more in order to apply the First Amendment.

By way of example, the court compared Saderup's charcoal sketches to Andy Warhol's silkscreens, noting the contrast involved. ${ }^{162}$ Both artists infringed the right of publicity by realistically recreating conventional celebrity faces, but Warhol's works would be entitled to First Amendment protection because through "distortion and the careful manipulation of context, Warhol was able to convey a message that went beyond the commercial exploitation of celebrity images and became a form of ironic social comment on the dehumanization of celebrity itself." 163 Thus, Warhol transformed an otherwise conventional likeness into something more by adding creative expression that amounted to social commentary.

On the other hand, Saderup's work involved "no significant transformative or creative contribution."164 In essence, Saderup was described as a free rider, and judges and juries often seek to punish free-riding. 165 The court held that his artistic skill, while undeniable, was leveraged in such a way as to capitalize on the conventional, and thereby instantly recognizable, celebrity image. ${ }^{166}$ But this reasoning sits uneasily in light of the Supreme Court's oftrepeated warning in the copyright context to judges against engaging in artistic evaluation. ${ }^{167}$ It seems like the California Supreme Court was doing just that, evaluating the artistic merits of Saderup's work-not just in the creative decisions he made but also in the meaning of the art itself. ${ }^{168}$ Warhol receives protection

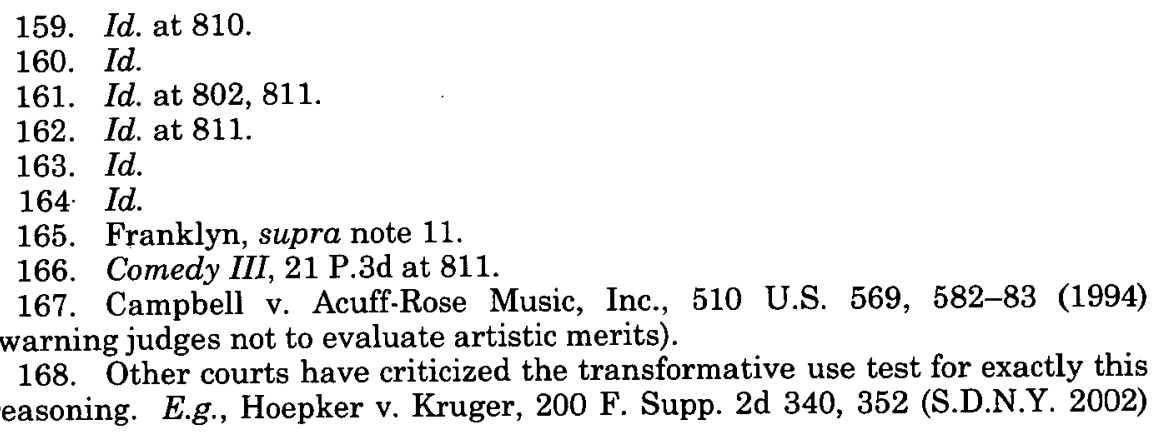


because his work rises to the level of social commentary, but a conventional depiction of the Three Stooges? No social comment. Thus, the larger, lingering problem with this decision revolves around the definition of "conventional" depictions.

The court closed its opinion with a disclaimer that the transformative use test "does not express a value judgment or preference for one type of depiction over another."169 But how can this be so when the court explicitly describes how Andy Warhol would receive protection because of the values conveyed by his art while Gary Saderup would not?170 Indeed, whether a depiction is conventional or not goes to the very heart of an artistic-value judgment.

The Comedy III decision is, at its core, a reasonable and pragmatic way to approach the right of publicity and the potential for the First Amendment to swallow the rule. An artist that simply takes a fungible celebrity image for his own gain does not deserve a complete First Amendment defense because he has not added any distinct value by his own creativity and engages in free riding.171 But the court has to dress up an otherwise straightforward economic division of added value in an ultimately unsatisfying way because of the First Amendment's baggage.

While Comedy III represents the first application of the transformative use test in the right-of-publicity context, it is far from the last. In a little over a decade since the decision, multiple courts have used the test with varying degrees of satisfaction. ${ }^{172}$ In each decision, isolated elements of conventional imagery or contextual meaning appear and serve as the deciding point.173 But as the case law develops, it is clear that this test, which evaluates a broad spectrum of grey and ambiguity, is not well suited in a winner-take-all system.

\section{B. New York's Predominant Purpose Test}

A year after the California Supreme Court handed down the Comedy III decision, the Southern District of New York in the

("Courts should not be asked to draw arbitrary lines between what may be art and what may be prosaic as the touchstone of First Amendment protection.").

169. Comedy III, 21 P.3d at 811 .

170. We acknowledge that the comparison drawn was dicta, but such language has powerful effects that should not be discounted. See generally Foster Calhoun Johnson, Judicial Magic: The Use of Dicta as Equitable Remedy, 46 U.S.F. L. REv. 883, 887-88, 899 (2012) (describing the long-term and transformative power of dicta).

171. Franklyn, supra note 11 , at 143 n.152.

172. See, e.g., ETW Corp. v. Jireh Publ'g, Inc., 332 F.3d 915, 936 (6th Cir. 2003); No Doubt v. Activision Publ'g, Inc., 122 Cal. Rptr. 3d 397, 409-10 (Ct. App. 2011); Kirby v. Sega of Am., Inc., 50 Cal. Rptr. 3d 607, 615 (Ct. App. 2006).

173. See, e.g., ETW Corp., 332 F.3d at 936-38; No Doubt, 122 Cal. Rptr. 3d at $410-11$; Kirby, 50 Cal. Rptr. 3d at 616-17. 
Hoepker case expressly declined to adopt the transformative use test. 174 The court observed that the transformative test was flawed because it forced judges "to draw arbitrary lines between what may be art and what may be prosaic as the touchstone of First Amendment protection."175 Ironically, the court in practice conducted a functionally equivalent test and concluded by holding that the defendant had created art.

In Hoepker, the defendant artist cropped and enlarged a vintage-era photograph of the plaintiff and then superimposed a stylized caption on the image to create a composite montage that was displayed in an art exhibit (not unlike the memes discussed supra Subpart II.E). ${ }^{176}$ The defendant art museum also used the image on gift shop merchandise such as cards, magnets, t.shirts, and a coffee table book. ${ }^{177}$ The court refused to apply Comedy III and instead applied what can be called a predominant purpose test and analyzed whether the primary nature of the infringing use was commercial or not. 178 If the use was primarily noncommercial, such as the creation of art, then the First Amendment would provide a complete defense.179 In granting summary judgment for the defendants, the court held that "the museums are selling art, albeit on t-shirts and refrigerator magnets." 180

Here then is a case startlingly similar to Comedy III yet with a completely opposite outcome. Both defendants took an otherwise conventional image of the plaintiff and sold it on a t-shirt. The outcomes can be rationalized, but only by artistic evaluation. In Hoepker, the plaintiff's original photograph featured a 1950s-style woman holding a magnifying glass up to one eye, to which the defendant added the caption: "It's a small world but not if you have to clean it." 181 The foundation of the image was a photograph, by definition a conventional representation. Therefore, it was the added value of the caption that transformed an otherwise conventional image into art.

The addition of the caption generates a message-one interpretation is social commentary on the traditional role of women during the 1950s and 1960 s, analogous to the old proverb regarding the challenges of housework, "A woman's work is never done."182 In contrast, the depiction of the Three Stooges in Comedy III had no accompanying caption. Thus, there was no way for the court to even

174. Hoepker v. Kruger, 200 F. Supp. 2d 340, 349-54 (S.D.N.Y. 2002).

175. Id. at 352 .

176. Id. at 342 .

177. Id.

178. Id. at $352-54$.

179. Id. at 354 .

180. Id. at 353 .

181. Id. at 342 .

182. McGraW-Hill's Dictionary of American Idioms aNd Phrasal VerbS 764 (Richard A. Spears ed., 2005). 
infer a secondary meaning or message of the work other than free riding.

On the one hand, it makes sense that the Hoepker piece was protected - the defendant did not simply copy and paste the photo; she added value by imposing a stylized caption that changed the meaning of the work (and also made it distinctly her own). But on the other hand, the plaintiff received absolutely nothing for the use of her likeness. At least the court refused to award costs and fees ${ }^{183}$ to the defendant, but a better outcome would have allocated some portion of the profits to the plaintiff. Certainly, the brunt of the economic value would stay with the defendant, for it was her vision and creative labor that engendered such a positive public response. But can we say with a straight face that the plaintiff is entitled to absolutely nothing for having her publicity property right circumvented to sell t-shirts, magnets, and mugs?

\section{ETW and the Transformative Contrast}

The Sixth Circuit in ETW employed the transformative use test in addition to a more complete fair-use analysis based on the Restatement (Third) of Unfair Competition. ${ }^{184}$ Artist Rick Rush created and sold a painting commemorating Tiger Woods's 1997 championship golf win. ${ }^{185}$ The painting depicted a conventional Woods from three angles in different poses, including his "famous golf swing." 186 In addition, the faces of previous winners were transposed across the top of the painting along with the trappings of the golf course, such as the green and the clubhouse.187

Again, the court distinguished between merchandise and art, describing how "[a] piece of art that portrays a historic sporting event communicates and celebrates the value our culture attaches to such events." 188 The court found that the additional elements (i.e., the likenesses of past winners and the image of the clubhouse) apart from Tiger Woods were themselves sufficient to bring the work within the protection of the First Amendment. ${ }^{189}$ The court concluded that the artist had transformed the work because it did not capitalize solely on a conventional depiction of Woods but also

183. Hoepker, 200 F. Supp. 2d at 355. Other plaintiffs are not so fortunate and have had fees imposed. E.g., Kirby v. Sega of Am., Inc., 50 Cal. Rptr. 3d 607, 618-19 (Ct. App. 2006).

184. ETW. Corp. v. Jireh Publ'g, Inc., 332 F.3d 915, 937 (6th Cir. 2003).

185. Id. at 918. An original serigraph is still available for $\$ 3000$ directly from the artist. The Masters of Augusta, RICK RUSH, http://rickrushart.com /index.php?main_page=index\&cPath=43_45 (last visited Aug. 3, 2014).

186 ETW Corp., 332 F.3d at 918, 947.

187. Id. at 918 .

188. Id. at 936 .

189. Id. But see Hart II, 717 F.3d 141, 169 (3d Cir. 2013) (ignoring additional elements because they did not implicate the plaintiffs specific right of publicity). 
"convey[ed] the message that Woods himself will someday join that revered group [of previous winners]." 190

The court reached this outcome despite survey evidence offered by the plaintiff for a failed trademark claim that indicated consumer confusion as to "Woods being the origin or sponsor" of the painting. ${ }^{191}$ The dissenting judge indicated that he would have entered summary judgment on the right of publicity claim in favor of Woods because his likeness was the focal point for the work: "[I]t is clear that the prints gain their commercial value by exploiting the fame and celebrity status that Woods has worked to achieve." 192 The dissent further criticized the majority for focusing too much on the "trappings" and ignoring the plain reality that the conventional image of Woods drove the work. 193

How then is this decision reconciled with the prior cases? The court found first that the defendant had added value by including additional elements that were not Woods's likeness. But that consumers were buying prints for these additional elements is irrelevant, speculative, or marginal at best. ${ }^{194}$ Woods was center stage, three times over, wearing his famous red shirt and posing with his famous golf swing. The court, apparently sensing this weakness, bolstered their transformative-use finding by explaining that the defendant had added value in the form of a message. But the message is essentially circular: Tiger Woods, champion golfer, is destined to be a golf legend.195 In short, this seems exactly like the sort of conventional image use that the right of publicity is meant to protect against. 196

One potential explanation for the inconsistency is that the judges were really engaging in an economic evaluation that the extant framework cannot accommodate. The First Amendment either yields to the right of publicity or it does not; thus, Rick Rush either continues to sell the prints or must disgorge the profits. There exists no mechanism that would allow the judges to impose a compulsory license on Rick Rush, obligating him to pay a percentage to Tiger Woods but maintaining his right to create (speak) and monetize the product. 197

190. ETW Corp., 332 F.3d at 936.

191. Id. at 939 .

192. Id. at 960 (Clay, J., dissenting).

193. Id. ("Accordingly, contrary to the majority's conclusion otherwise, it is clear that the prints gain their commercial value by exploiting the fame and celebrity status that Woods has worked to achieve.").

194. Id. at 959 (describing how Woods is the primary focus of the print).

195. Id. at 936 (majority opinion).

196. Id. at 960 (Clay, J., dissenting) ("Under such facts, the right of publicity is not outweighed by the right of free expression.").

197. See MCCARTHY, supra note $13, \S 8: 72$ ("Rather, what is going on is a rule of law that requires a court to decide if the accused work has enough 'transformative' elements to deserve a free speech defense from liability. There 


\section{Application of the Right of Publicity to Videogames}

Videogames represent a particularly interesting field for the right of publicity because of all the creative labor that is involved in development. Videogames share many elements with traditional media, such as art design and story creation. But one element that makes videogames particularly unique and also particularly challenging to analyze from a right-of-publicity perspective is that they are interactive. A movie, advertisement, or story is a one-way interaction-the viewer simply consumes the director's creative expression. Videogames, on the other hand, force the viewer to interact with the director's expression, and some games allow for extensive customization and modification. In short, videogames offer ample opportunity to add value in multiple dimensions, and the courts have struggled to accommodate the new medium.

\section{Transforming Pop Stars}

In 2006, California applied the transformative use test in the videogame case Kirby. 198 There, the plaintiff, Kierin Kirby, better known as pop star Lady Miss Kier, claimed that the videogame company Sega had infringed her likeness by modeling the main player character after her in the videogame Space Channel 5.199 The character had similarities to Kirby in appearance, hairstyle, clothing choice, and dance moves. ${ }^{200}$ Kirby furthermore claimed that Sega had approached her, but that she refused to grant them a license. ${ }^{201}$ She argued that even the character's name, "Ulala," was a play on her catch phrase, "ooh la la." 202 Ultimately, the court not only found Sega's use transformative, but also ordered Kirby to pay over half-a-million dollars in fees and costs. 203

Despite these similarities in likeness, the court nonetheless held in favor of the defendants because of the creative context and setting, which cast the alleged Kirby-like character as a twentyfifth-century news reporter that used dance moves to foil an alien

is a spectrum of works that 'transform' the subject to some extent-some have 'enough' creative elements, others do not. It is a subjective judgment call along a spectrum of transformations. It is not a mechanical sorting of artistic and expressive works into two clearly differing categories, some that 'transform' and some that do not 'transform' at all.").

198. Kirby v. Sega of Am., Inc., 50 Cal. Rptr. 3d 607, 615 (Ct. App. 2006) (applying the "straightforward" transformative test).

199. Id. at 609 .

200. Id. at $609-10$.

201. Justinian Lane, "Lady Miss Kier" Hammered with Opponent's Attorney's Fees, LEGAL READER, http://www.legalreader.com/2006925lady-misskier-hammered-with-opponents-attorneys-fees-html/ (last visited Aug. 2, 2014).

202. Kirby, 50 Cal. Rptr. 3d at 613. Catch phrases have been held to be elements of actionable likeness. See, e.g., Carson v. Here's Johnny Portable Toilets, Inc., 698 F.2d 831, 834 (6th Cir. 1983).

203. Kirby, 50 Cal. Rptr. 3d at 618 (awarding $\$ 608,000$ in fees and costs). 
invasion. ${ }^{204}$ Kirby argued that the videogame did not change the meaning of her likeness or deliver any message, such as the social commentary that the California Supreme Court, in Comedy III, said in dicta would have immunized Warhol's works. ${ }^{205}$ The court, though, found that the transformative use test was "straightforward" 206 and responded: "A work is transformative if it adds 'new expression.' That expression alone is sufficient; it need not convey any 'meaning or message."'207

Kirby represents perhaps the opposite end of the spectrum from Comedy III and embodies particularly transformative elements. The idea of a twenty-fifth-century news reporter using dance moves to stop an alien invasion is admittedly a particularly creative and transformative use for a 1980s pop star's likeness. Furthermore, the defendant expended substantial labor to create the videogame and all its trappings, ranging from sound effects to level design and art rendering. ${ }^{208}$

But at the same time, there is lingering unease, particularly if one accepts that Kirby had actually denied Sega a license. At the core, the game is about singing and dancing, which is a conventional type of activity for which the plaintiff was known, and featured a character model that was at least inspired by the plaintiff. To be sure, the trappings are creative and elevate the speech out of blatantly infringing territory; but this outcome, replete with the award of fees, represents another situation where the winner truly took all.

\section{Non-Transformative Pop Stars}

More recently, the band No Doubt won a lawsuit against Activision for the use of their likeness in the game Rock Band.209 This situation is contrasted against Kirby because it is more clearcut. The game Rock Band, as its name implies, simulates the performance experience of a rock star by allowing the player to perform songs as a digital avatar. ${ }^{210}$ The player presses buttons in a certain order to perform the songs, and, as they successfully complete more performances, they gain access to more songs, singers, and customization options. ${ }^{211}$

204. Id. at $610,616-17$.

205. Id. at 616-17.

206. Id. at 615 .

207. Id. at 617 (quoting Comedy III Prods., Inc. v. Gary Saderup, Inc., 21

P.3d 797, 807-08 (Cal. 2001)).

208. Id. at $609-10$.

209. No Doubt v. Activision Publ'g, Inc., 122 Cal. Rptr. 3d 397, 415 (Ct. App.

2011) (including an award of costs and fees).

210. Id. at 401 .

211. Id. 
Activision realistically rendered the band members as digital avatars so that they were close to conventional depictions. ${ }^{212}$ Activision had actually licensed a limited use of No Doubt's likenesses. ${ }^{213}$ The issue was that the scope of the license was exceeded when Activision implemented a code that allowed players to "unlock" the avatars and use them to perform any song in the game, not just their assigned songs. ${ }^{214}$

Activision argued that the unlock feature did not trespass on the right of publicity because it allowed the avatars to be placed into fanciful contexts, such as outer space and the future. ${ }^{215}$ In this way, Activision tried to isolate issues from Kirby that the court found persuasive-like the fanciful setting. Ultimately, the argument failed, and the court held that it was not enough added value to transform the work. ${ }^{216}$ The sticking point seemed to be that even in fanciful contexts it was still conventional rock star avatars performing conventional rock songs. ${ }^{217}$

\section{Transforming Sports Stars}

The right-of-publicity lawsuit that was until recently pending before the Supreme Court encapsulates and brings to the forefront the problems with right-of-publicity jurisprudence. ${ }^{218}$ EA published a college football videogame franchise annually since 1993.219 As a result of these pending lawsuits, EA not only settled to the tune of $\$ 40$ million (estimated at $\$ 300$ per player), but has also decided to retire the multi-million dollar franchise over right-of-publicity concerns. ${ }^{220}$ Even though EA decided to settle, the petition for certiorari to the Supreme Court was still on the docket until

212. Id. at 411 (noting the conventional portraits).

213. Id. at 400 .

214. Id. at 401-02.

215. Id. at 410 .

216. Id. at 415 .

217. Id. at 411.

218. For clarification, there are three lines of cases: In re NCAA StudentAthlete Name \& Likeness Licensing Litigation (Keller), 724 F.3d 1268 (9th Cir. 2013), cert. dismissed, No. 13-377 (U.S. Sept. 30, 2013), Davis v. Electronic Arts Inc., No. 10-03328 RS, 2012 WL 3860819 (N.D. Cal. Mar. 29, 2012), and Hart II, 717 F.3d 141 (3d Cir. 2013). For our purposes, we focus on the Hart case because it features a broader discussion for us to draw on. The cases are otherwise functionally identical, apply the same transformation test, and reach the same conclusions on appeal. Id. at $163 \mathrm{n} .28$ ("Both cases concern right of publicity claims asserted against EA for use of football players' likenesses in their game franchises. Davis related to EA's Madden NFL games while Keller is simply our own case incarnated in California. In both disputes the court applied the Transformative Use Test, and in both instances the court decided that EA's use of the players' likenesses failed the Test.").

219. Hart II, 717 F.3d at 146.

220. Owen Good, College Players Can Get a PS4 from a Bowl Game, but They Can't Be Paid, KoTAKu (Dec. 9, 2013, 7:30 PM), http://kotaku.com/collegeplayers-can-get-a-ps4-from-a-bowl-game-but-the-1479891400. 
recently, ${ }^{221}$ and the NCAA, who stood to lose much more than a videogame franchise, intended to argue it all the way. ${ }^{222}$ The NCAA also sought to intervene in the settlement, but the Supreme Court denied the motion. 223

The design of the game has stayed relatively static-it is a football simulation allowing players to take on the role of coach or player. ${ }^{224}$ As technology progressed over the franchise's seventeenyear history, the visual experience of the game went from little more than sixteen-bit pixel icons to photorealistic renderings of players, complete with motion capture and dozens of stadiums. Customers demanded realism, and EA invested in state-of-the-art-rendering technology.225 Each iteration of the game accurately modeled players on their real life counterparts and features customizable statistics based on height, weight, build, race, and even clothing accessories. ${ }^{226}$ EA also included accurate biographical information such as hometowns. ${ }^{227}$ The particular names of players, however, were not reproduced, ${ }^{228}$ although they were readily identifiable based on physical appearance. Even then, the game's interactive customization features allowed players to assign names to the rosters and then upload and share that data with other players. ${ }^{229}$

Former college players sued EA and the NCAA; among their claims, they alleged that their likenesses had been used without compensation. ${ }^{230}$ In defense, EA argued that the First Amendment protected the use. ${ }^{231}$ The district court, in holding for EA, observed

221. Keller, 724 F.3d 1268, cert. dismissed, No. 13-377 (U.S. Sept. 30, 2013), available at http://www.supremecourt.gov/Search.aspx?FileName=/docketfiles 113-377.htm.

222. Berkowitz, supra note 3 (quoting Donald Remy, NCAA Chief Legal Officer, who stated, "We're prepared to take this all the way to the Supreme Court if we have to").

223. Nat'l Collegiate Athletic Ass'n v. Keller, 134 S. Ct. 980 (2014) (mem.) (denying the NCAA leave to file a petition for writ of certiorari). It is important to note that there are separate contractual rules enforced by the NCAA that restrict college players' right to accept any sort of endorsement money, including licensing their right of publicity. NCAA Rules-Media and Private Internet Websites, NCAA, http://grfx.cstv.com/photos/schools/samf/genrel/auto _pdf/Media_Internet_Sites.pdf (last visited Aug. 2, 2014). But for the sake of analysis, this issue will be set aside.

224. Hart II, 717 F.3d 141, 146 (3d Cir. 2013).

225. See id.

226. Hart v. Elec. Arts, Inc. (Hart I), 808 F. Supp. 2d 757, 761 (D.N.J. 2011), rev'd, 717 F.3d 141 (3d Cir. 2013).

227. Hart $I I, 717$ F.3d at 146.

228. See Hart I, 808 F. Supp. 2 d at 761.

229. Id.; see also NCAA Football Rosters, OPERATION SPORTS, http://www.operationsports.com/forums/ncaa-football-rosters/ (last visited Aug. 2 , 2014) (providing a forum for players to post and discuss NCAA Football rosters).

230. Hart $I, 808$ F. Supp. 2 d at 761.

231. Id. at 764 . 
that it presented a closer case than Kirby and No Doubt on the transformative continuum. ${ }^{232}$ They hinged their analysis on the consumer's ability to interact with the game and alter the player avatars. 233 The court held that the customization options were enough in and of themselves to transform the game, but that additional "trappings" of the game, including "virtual stadiums, athletes, coaches, fans, sound effects, music, and commentary," decisively transformed the likeness into First Amendment expression. ${ }^{234}$

On appeal, the decision was squarely reversed. ${ }^{235}$ The appellate court indicated that the district court misapplied the test for two reasons. First, the "trappings" and other creative elements of the videogame (e.g., stadiums, music, and crowds) were irrelevant because they did not bear on how the celebrity's identity was used. ${ }^{236}$ Second, the mere presence of customization options for the player avatars was a trivial variation. ${ }^{237}$

Not only did the court deem the customization features insufficient, they basically discounted the entire notion, holding that "once a user has made major changes to the avatar, it no longer represents Appellant, and thus it no longer qualifies as a 'use' of the Appellant's identity for purposes of our inquiry."238 Conceptually, it means that avatar customization features may never be transformative (which is what the district court based its holding on)-any minor customization would be a "merely trivial" variation, and any major customization may not even be considered a "use" in the first place.

232. Id. at 783 ("Here, NCAA Football's use of Hart's image presents a closer call than that in Kirby and No Doubt.").

233. Id. (observing that personal characteristics, accessories, physical abilities, attributes, and biographical details of players can all be edited by the user).

234. Id. at 784; see also id. at 785 ("What matters for my analysis of EA's First Amendment right is that EA created the mechanism by which the virtual player may be altered, as well as the multiple permutations available for each virtual player image.... In my view, the creation of these varied potential formulations of each virtual player alone makes the game a transformative use of Hart's image.").

235. Hart II, 717 F.3d 141, 145 (3d Cir. 2013).

236. Id. at 169 ("Decisions applying the Transformative Use Test invariably look to how the celebrity's identity is used in or is altered by other aspects of a work. Wholly unrelated elements do not bear on this inquiry.").

237. Id. at 168 ("The ability to make minor alterations-which substantially maintain the avatar's resemblance to Appellant (e.g., modifying only the basic biographical information, playing statistics, or uniform accessories)-is likewise insufficient, for '[a]n artist depicting a celebrity must contribute something more than a "merely trivial" variation." (quoting Winter v. DC Comics, 69 P.3d 473, 478-79 (Cal. 2003))).

238. Id. at 169 . 
Underneath it all, the appellate court simply applied Comedy III in the most narrow ${ }^{239}$ and conventional of ways: both the use of the likeness and the context of the use were conventional per Comedy III. There was nothing fanciful or particularly creative about using a college football player's likeness in a college football videogame. And yet the all-or-nothing result is dissatisfying because the remedies ignore anything on the other side of the equation. EA expended substantial labor to create the game, and, as in most team sports, no particular likeness predominated the game. Beyond that, the player information, statistics, and names were in the public domain according to the district court, citing to an Eighth Circuit decision for support. 240

The dissenting Judge Ambro noted this discrepancy: "[B]y cabining their inquest to Hart's likeness alone, their approach is at odds with California Supreme Court decisions on the Transformative Use Test."241 The dissent cited a California Supreme Court decision warning judges that focusing on realistic depictions or commercialism would have a chilling effect on speech.242 Judge Ambro went on to argue that the majority's emphasis on a realistic portrayal and profitability created "a medium-specific metric that provides less protection to video games than other expressive works." 243

The dissent argued that the outcome is different depending on the frame of reference, which is a classical problem in intellectual property. He explained that the end consumers were "not reenacting real games, but rather are directing the avatars in invented games and seasons." 244 The majority framed it as conventional avatars in conventional football games, but the dissent framed it as avatars in unconventional football games that have never been played before and will never be played again. ${ }^{245}$ For the dissent, the product represented a sandbox, and no infringement

239. Id. (" $[\mathrm{W}]$ e hold that the broad application of the Transformative Use Test represents an inappropriate application of the standard. Consequently, we shall not credit elements of NCAA Football that do not, in some way, affect the use or meaning of Appellant's identity.").

240. Hart I, 808 F. Supp. 2d 757, 785 n.28 (D.N.J. 2011), rev'd, 717 F.3d 141 (3d Cir. 2013) (citing C.B.C. Distribution \& Mktg., Inc. v. Major League Baseball Advanced Media, L.P., 505 F.3d 818, 823 (8th Cir. 2007) (holding that First Amendment protection against a right-of-publicity claim applied to a fantasy football league operator where publicly available player names and statistics were used)).

241. Hart II, 717 F.3d at 172 (Ambro, J., dissenting).

242. Id. at 174 (citing Guglielmi v. Spelling-Goldberg Prods., 603 P.2d 454, 460-62 (Cal. 1979)).

243. Id.

244. Id. at 175 .

245. This reasoning is reminiscent of Gary Saderup's argument in Comedy III that each drawing was unique and therefore transformative. See Comedy III Prods., Inc. v. Gary Saderup, Inc., 21 P.3d 797, 810 (Cal. 2001). 
could exist until the player configured the sand, but by then it would be found sufficiently creative for First Amendment purposes. In the end, the dissent failed to see how the "[w]holly unrelated" creative elements could be divorced from the player's interactive experience using the plaintiff's likeness. ${ }^{246}$

The terminus of the majority's decision will practically foreclose development of any videogame that uses as source material any living or historical person with a viable postmortem right of publicity. ${ }^{247}$ The court defined a broad right of publicity and interpretation of Comedy III - as long as the use or portrayal of the likeness is conventional in some way, it could infringe the right. But even beyond that, the court is endowed with so much discretion in framing the context that it would be impossible to predict the outcome, and few developers may be willing to take the risk of a trial.

\section{HONESTLY ANALYZING COMPETING INTERESTS}

All these cases have some shared transformative use elements that have been judicially recognized in one way or another. The problem we have identified is not that the right is "bad," but that application and development has been undisciplined and overly discretionary, which has led courts into a quagmire of unnecessary analytical leaps. Judges are (rightfully) squeamish around the First Amendment given its venerated role in American society.

\section{A. Towards a Paid-For First Amendment}

The fundamental issue is that the rights at hand are inapposite-the property right of personality includes a censoring mechanism pitted against an anti-censoring freedom. The consensus is that any solution that allows the rights holder to censor is troubling at best. ${ }^{248}$ As the case-law discussion shows, there is no way to consistently rationalize the First Amendment with the right of publicity.

Contextual issues such as framing, abstraction, profitability, the state of the art, and celebrity culture have made the right of publicity too complex and far too subjective to be a reliable legal

246. Hart $I I, 717$ F.3d at 175 ("[T]hose [wholly unrelated] elements are, in fact, related to EA's use of Hart's likeness.").

247. William K. Ford \& Raizel Liebler, Games Are Not Coffee Mugs: Games and the Right of Publicity, 29 SANTA Clara COMPUTER \& HigH TeCH. L.J. 1, 88 (2012) (describing conflicts between the right of publicity, the First Amendment, and historical figures).

248. Diane Leenheer Zimmerman, Who Put the Right in the Right of Publicity?, 9 DePAUL-LCA J. ART \& ENT. L. 35, 66-67 (1998) (discussing how the Supreme Court avoided having to deal with "the more troubling relief of a prior restrain than [sic] would enable him to control or censor the use of his performance"). 
mechanism. The right is growing unchecked, and attempts to balance it against the First Amendment have resulted in a patchwork of misleading potential defenses. Integrating First Amendment principles, such as transformative use, into the right of publicity is an easy solution, but ultimately requires that "[t]he balance ... be laboriously hacked out case by case." 249 We believe that there may be an alternative solution.

Continuing down this case-by-case pathway will result in further fracturing, or worse; it could expand the right of publicity into an undisciplined replacement for copyright and trademark law. The right of publicity has far too much vested economic interest to dismantle it. Equally unapproachable is the notion of dismantling the First Amendment, at least in terms of censorship. However, the idea of a "pay-to-play" First Amendment is not only palatable-the Supreme Court has explicitly endorsed it.

\section{B. Judicial Justifications for a Paid-For First Amendment}

Back in Zacchini, the Supreme Court did something interesting. The specific holding is that the First Amendment does not require a press privilege in the circumstances of a news reporter publishing a performance artist's complete performance. ${ }^{250}$ In its analysis, the Court repeats several times that the petitioner was not seeking to censor speech, but "simply want[ed] to be paid for it."251

In explaining how the petitioner was not seeking to censor expression or chill the news, the Court essentially drew out a copyright concept known as the idea/expression dichotomy. ${ }^{252}$ The First Amendment would protect the news agency from reporting facts and ideas about the performance, but it would not protect them from broadcasting the entire expressive performance. ${ }^{253}$ The Supreme Court drew a line in the sand between the First Amendment and the right of publicity. If the public sought the benefit of anything further, someone would have to pay. ${ }^{254}$

Our theory is that this line is sufficient for the First Amendment and that the right of publicity should otherwise be "deconstitutionalized." We propose a compulsory license for the use of

249. MCCARTHY, supra note $13, \S 8: 39$.

250. Zacchini v. Scripps-Howard Broad. Co., 433 U.S. 562, 578-79 (1977).

251. Id. at 578 (recognizing and upholding the right of publicity).

252. In copyright law, ideas and facts are unprotected speech elements in the public domain. Feist Publ'ns, Inc. v. Rural Tel. Serv. Co., 499 U.S. 340, 350-51 (1991). Zacchini could not monopolize the idea of a human cannonball (anyone else was free to create his or her own cannonball show); nor could Zacchini prevent others from reporting the factual event of his performance (there was a man named Zacchini who indeed was fired out of a cannon).

253. Zacchini, 433 U.S. at 574-75.

254. Id. at 578 (" $[\mathrm{N}]$ either the public nor respondent will be deprived of the benefit of petitioner's performance as long as his commercial stake in his act is appropriately recognized."). 
privately owned speech. What this does is essentially shift the judicial focus away from convoluted and problematic balancing tests and towards more efficient economic division. Judges would not have to contrive secondary meanings to works that are plainly superficial in order to avoid the all-or-nothing outcomes.

\section{What Happens When an Immovable Force Meets an Unstoppable Object?}

The answer is nothing; they cancel each other out, and the unstoppable object will pass right through the immovable force. 255 The point is that the defendant's freedom to conjure the plaintiff's likeness is equally and oppositely counteracted by the plaintiff's right to prevent his likeness from being conjured. The most reasonable solution to this otherwise paradoxical conflict is to simply allow the forces to pass through each other and bill for it.

In all of the previous cases, it would have been much better for all parties involved if some of the profits were split up. This is the crux of it and should be an acceptable price of fame. In order to preserve participatory access to popular culture, celebrities must yield their likenesses to use by others. At the same time, in order to preserve the integrity of the property right, defendants must cede some portion of the profit to the celebrity. In truest Lockean form, the labor used in generating raw material of celebrity and in remixing that raw material into something else, however transformative or nontransformative it may be, should be rewarded in kind.

This framework would not change the outcomes of cases that much but would soften the remedy and allow more flexibility to account for context. Think back to the cases that were decided in the defendants' favor, like Hoepker, ETW, and Kirby. In each of those cases, the court denied the plaintiff any relief because the First Amendment worked as a complete defense to the use of their likeness. Our proposed framework changes the outcome only insofar as the defendant must return a nominal portion of their profits.

As Professor Netanel described in his article on copyright and the First Amendment: the free market is the best arbiter of value. ${ }^{256}$

255. MinutePhysics, Immovable Object Vs. Unstoppable Force-Which Wins?, YouTUBE (Jan. 25, 2013), https://www.youtube.com/watch?v $=9 \mathrm{eKc} 5 \mathrm{kgPVrA \# t}=23$.

256. Neil Weinstock Netanel, Copyright and a Democratic Civil Society, 106 YALE L.J. 283, 309 (1996) ("[C]opyright is primarily a mechanism for market facilitation, for moving existing creative works to their highest socially valued uses. Copyright can best serve this goal, neoclassicism suggests, by enabling copyright owners to realize the full profit potential for their works in the market.... For neoclassicists, copyright enables owners to charge users for access to creative work public goods not so much to preserve author incentives as to determine what creative works are worth and thus to create a guide for resource allocation."). 
If the defendant's use of a likeness is not an optimal one, the market will respond in kind by denying the defendant any substantial profit. The plaintiff celebrity, who is upset because he is not compensated, receives a proportional share of the profit. Thus, the First Amendment would be conditioned on money. A de minimis profit could serve as a threshold barrier to a right-of-publicity claim.

This makes logical sense; if the plaintiff is suing based on the right of publicity purely to silence the defendant, the First Amendment is more likely than not offended by such an action as a form of censorship. In such a scenario, the defendant may rely on an anti-SLAPP motion.257 Alternatively, the right-of-publicity statute could be amended to reflect a profit threshold. But if the plaintiff is suing to get a cut of the profit, then the issue shifts from one of censorship to one of economic distribution. This is the issue we are targeting. The plaintiff rightfully deserves a cut of that profit, and, at the same time, the defendant deserves to make their expression.

But it should not be up to the plaintiff to decide her own royalty rate because this would allow back-door censorship through unrealistic and usurious pricing. As such, the mechanism could be compulsory and proportional to the gross revenue attributable to the presence of the plaintiff's property right. In addition, awards of attorney fees and costs should to be limited or potentially even circumscribed. Where the property-right infringement can be shown to have had a negligible effect, the plaintiff would be entitled to a token percentage. The Kirby plaintiff would probably fall into this category. Certainly, her likeness was recognizable, but the defendants added so much value to her raw materials that it is extremely unlikely that the consumers were purchasing the product based on her presence. On the other end of the spectrum is ETW, where the plaintiff, Tiger Woods, was able to show with survey evidence that consumers were purchasing the work because of a perceived endorsement by Woods.

The critical point, though, is that the plaintiff would not have the power to enjoin the defendant from creating and distributing the work. ${ }^{258}$ Tiger Woods would get a percentage of the profits that the jury felt was attributable to his likeness as opposed to the added value of the defendant. But this ultimately allows the judge to split

257. Eric David, A Brief Overview of Anti-SLAPP Statues, Newsroom L. BLOG (Jan. 15, 2009), http://www.newsroomlawblog.com/2009/01/articles /antislapp-statutes/a-brief-overview-of-antislapp-statutes/ ("[A]nti-SLAPP statutes are laws designed to prevent plaintiffs from using the threat of costly litigation to chill the free speech rights of people seeking to participate in the public debate over important issues.").

258. Zimmerman, supra note 39 , at 731-32 (warning that the First Amendment would be "crabbed" if a license to use right-of-publicity speech could be withheld at will). 
the difference-the defendant gets to keep some of his profit and is allowed to express his speech, and the plaintiff gets a cut of the profit as well. Furthermore, judges will be able to deal with the economic and labor evaluation honestly and without the pretense of "transformation."

Plaintiffs may groan at this framework because they want complete control. But as discussed in prior Parts of this Article, the very foundation of celebrity fame as a solo accomplishment is circumspect. Why then should they be entitled to exclusive control in the right-of-publicity context?259 But beyond that, as the Supreme Court famously observed, plaintiffs in this field are generally not upset that their likenesses have been used, but that they were not compensated for the use. ${ }^{260}$ Our proposed resolution cuts to the chase.

The defendants also sacrifice some rights at the fringe of the First Amendment. Formerly, if a defendant could make a sufficient showing of transformative use, then the plaintiff was entitled to nothing at all even if obvious elements of the likeness were present. For example, if the Hoepker facts were decided under our proposed system, the defendants would have to pay some nominal percentage of the profits to the plaintiff for the use of her likeness. In that case, the gross proceeds were somewhere around $\$ 400,000$ from all the materials, but only a fraction of that profit directly involved the plaintiff's likeness, and then only a fraction of that profit was directly attributable to the use of her likeness. ${ }^{261}$

The most challenging aspect of this law is that it will force some content creators that use extremely large volumes of likenesses to spend more time apportioning values. Really, this challenge exists

259. See Madow, supra note 41, at 196 (arguing that celebrities cannot say that they are solely responsible for their public image and therefore "cannot lay a convincing moral claim to the exclusive ownership or control of the economic values that attach to it").

260. Zacchini v. Scripps-Howard Broad. Co., 433 U.S. 562, 578 (1977).

261. See Hoepker v. Kruger, 200 F. Supp. 2d 340, 343 (S.D.N.Y. 2002) (stating the individual gross proceeds and net revenue for each defendant, which accumulated to aggregate gross proceeds of $\$ 427,593$ and net revenues of around $\$ 140,000) ; i d$. at 351 (holding that the plaintiff's right-of-privacy action "falls outside the sphere of activity prohibited by New York's privacy statutes" because the advertisements undertaken by the museum "merely "prove[d] the worth and illustrate[d] [the] content" of the museum and the art exhibit which displayed the image in dispute (quoting Groden v. Random House, Inc., 61 F.3d 1045, 1049 (2d Cir. 1995)); id. at 353 (finding that the plaintiff's image "was affixed to various gift items not to flaunt her visage, but because the gift items reproduced the Kruger Composite, a work of art displayed by the [museum] in its museum galleries"). Although the court did not dismiss the plaintiff's claims on this ground, the defendants argued that the court lacked jurisdiction because the plaintiff could not satisfy the jurisdictional amount required for diversity cases - even if the plaintiff was "entitled to recover all profits made from the sale of the Kruger catalog and the gift merchandise, her recovery would not add up to $\$ 75,000$ against any of the defendants." Id. at 354 . 
under the current legal framework anyway. And in any case, this seems like a minor inconvenience in relation to the staggering uncertainty and contingency that is embodied in the current law's all-or-nothing model. Furthermore, apportionment has long been a tested principle in copyright law. ${ }^{262}$

\section{CONCLUSION}

The right of publicity is on an unsustainable path in the digital era. The shadow cast by the First Amendment has caused courts to confuse their analyses in order to avoid looming constitutional issues. But no matter how many acrobatics judges engage in, the First Amendment will always be visible on the horizon. This has turned the transformative use test into an unpredictable and inconsistent device hinging on too much discretion to be useful.

In order to save both of these important rights, we must allow judges to honestly deal with the underlying economic issues. We can only accomplish this by transitioning to a compulsory licensing system. In order to satisfy the First Amendment, censorship must be taken off the table as a plaintiff tool. But to satisfy the right of publicity, mandatory profit sharing mechanisms must be implemented.

It may be observed that under this scheme neither right maintains the scope of power it had before. In any case, the spirit of the law is preserved. The First Amendment continues to prevent censorship, and the right of publicity continues to provide a profit asset. And, true to our goal, it gives judges more freedom to honestly engage with the issues of economic allocation. In turn, society benefits from a more diverse and open body of expression that can better leverage the shared cultural meanings of celebrity.

262. See Sheldon v. Metro-Goldwyn Pictures Corp., 309 U.S. 390, 402-05 (1940). 
